This is a pre-print of an article published in Journal of Macroeconomics. The final authenticated version is available online at: https://doi.org/10.1016/j.jmacro.2018.08.007 


\title{
Income Inequality and Banking Crises: Testing the Level Hypothesis Directly
}

\author{
Giorgio Bellettini* $\quad$ Flavio Delbono ${ }^{\dagger} \quad$ Peter Henning Karlstroem ${ }^{\ddagger}$ \\ Sergio Pastorello ${ }^{\S}$
}

December 23, 2017

\begin{abstract}
We perform an empirical analysis to investigate the relationship between income inequality and the occurrence of banking crises on a panel of 33 advanced countries in the period 1970-2011. As opposed to other empirical studies, we focus on levels rather than growth rates of income inequality. We find a statistically significant and positive relationship between the value of the Gini index and the probability of banking crises. This result is confirmed when income distribution is summarized by the top $1 \%$ income share.
\end{abstract}

JEL codes: D310, G010

Keywords: Income inequality; Banking crises; Credit booms

\footnotetext{
*Department of Economics, University of Bologna, Piazza Scaravilli, 2, 40126 Bologna, Italy. Email: giorgio.bellettini@unibo.it [Corresponding author]

${ }^{\dagger}$ Department of Economics, University of Bologna, Piazza Scaravilli, 2, 40126 Bologna, Italy. Email: flavio.delbono@unibo.it

${ }^{\ddagger}$ Department of Economics, University of Bologna, Piazza Scaravilli, 2, 40126 Bologna, Italy. Email: peter.karlstroem@unibo.it

$\S$ Department of Economics, University of Bologna, Piazza Scaravilli, 2, 40126 Bologna, Italy. Email: sergio.pastorello@unibo.it
} 


\section{Introduction}

In recent years, it has been claimed by some prominent scholars that income inequality may be responsible for financial crises. This point of view is well summarized in the influential book by Rajan (2010, p. 43), according to whom "growing economic inequality in the United States led to political pressures for more housing credit. This pressure created a serious fault line that distorted lending in the financial sector". While the argument is not fully new (see Galbraith , 1954, for instance), other researchers (e.g., Krugman, 2007, Fitoussi and Saraceno, 2009 and Stiglitz, 2012, among others) have endorsed what is now referred to as the "Rajan hypothesis", linking income inequality to the surge in household indebtedness which has been found to be a major predictor of banking crises. $^{1}$

The hypothesis put forward by Rajan and other scholars has triggered a vigorous debate (see the exhaustive and updated surveys by Van Treeck, 2014 and Bazillier and Hericourt, 2017), and a relatively small group of studies have tried to investigate empirically the relationship between income inequality and the occurrence of banking or financial crises. We aim at participating to this growing debate by means of an econometric analysis that tests the link between levels of income inequality and the probability of banking crises. Differently from other scholars (see in particular Bordo and Meissner, 2012 and Perugini, Hölscher and Collie, 2016) we test this link directly. Our study encompasses a panel of 33 advanced countries in the period 1970-2011. The main finding of our paper is that the level of gross income inequality (measured by either the Gini index or the top $1 \%$ income share) is positively associated with the occurrence of banking crises. Furthermore, we find that the effect of an increase in the level of income inequality is relatively large in economic terms. In addition, the effect seems to be larger for countries that already have an elevated level of income inequality. Finally, the results hold for a series of robustness checks, such as the exclusion of various country groups.

There are several reasons to claim that the relevant measure of income inequality is the level and not the growth rate when investigating if there is an association between income inequality and the likelihood of banking crises. First of all, the theoretical literature by Iacoviello (2008) and Kumhof, Ranciere and Winant (2015) emphasizes the existence of a long-run relation between household debt and income inequality. As a consequence, the use of the growth rate of income inequality that removes the long-run trend as in the studies by Bordo and Meissner (2012) and Kirschenmann, Malinen and Nyberg (2016) seems problematic. In fact, using the growth rate of income inequality will lead to biased estimates if a long-run relation exists between income inequality and household debt as emphasized by Klein (2015). Iacoviello (2008) argues that

\footnotetext{
${ }^{1}$ See also Kirschenmann, Malinen and Nyberg (2016). Iacoviello (2008) shows that in the U. S. the prolonged rise of the 1980 s and the 1990s in household debt can be quantitatively explained only by the concurrent increase in income inequality. See also Roy and Kemme (2012).
} 
short-term movements in household debt can be explained by business cycle fluctuations while the connection between household debt and income inequality is a long-term one. Klein (2015) uses panel cointegration techniques, and shows that a long-run relation exists between income inequality and household debt. This result is consistent with Malinen (2016), who also finds a long-run steady-state relationship between the top $1 \%$ income share and domestic bank credit. In short, both the theoretical and empirical literature emphasize that income inequality is related to household debt only in the long-run, which implies that the level of income inequality (rather than the growth rate) is the suitable measure in this study.

This paper is organized as follows. Section 2 reviews the related literature and places our analysis in perspective with respect to other empirical studies. Section 3 describes the dataset and variables. In Section 4 we provide a description of our empirical approach and the statistical model (4.1) followed by a discussion of our findings (4.2) and their robustness (4.3). Section 5 concludes.

\section{Related literature}

The first paper that investigates directly the relationship between income inequality and banking crises is Atkinson and Morelli (2011). Their approach is purely descriptive and focusses on the presence of a link between increases in income disparity (as measured by the Gini index as well as the top $1 \%$ income share) and the occurrence of banking crises in 25 countries between 1911 and 2010. They fail to detect any meaningful link between increases in income inequality before the occurrence of banking crises and the occurrence itself.

A similar conclusion is reached by Bordo and Meissner (2012) in a paper which became a benchmark for the subsequent literature. They test the Rajan hypothesis for a sample of 14 advanced countries between 1870 and 2008 and find that a credit boom increases the probability of a banking crisis. ${ }^{2}$ However, they cannot detect any evidence that a rise in top income shares accelerate the boom. The strategy employed by Bordo and Meissner consists in investigating whether credit growth influences the likelihood of banking crises, and then verifying if a change in income inequality is associated with higher credit growth. In the first step, logit and OLS estimations are conducted with a binary banking crisis dependent variable and lagged real credit growth as independent variable. They show that credit growth in the previous two to five years is strongly and positively associated to a crisis. In the second step, the top $1 \%$ income share is regressed against cumulative growth in credit during the previous five-year period. They reject any relationship between credit growth and the growth in top income share.

Gu and Huang (2014) use data similar to Bordo and Meissner (2012), but reach different results, possibly because cross-section heterogeneity is taken into account by including countries that can be considered to be

\footnotetext{
${ }^{2}$ A similar conclusion is reached by Schularick and Taylor (2012). Using a new historical dataset for 14 countries over the years 1870-2008, they conclude that credit growth is a powerful predictor of financial crises.
} 
outliers. Kirschenmann, Malinen and Nyberg (2016) perform logit estimations to investigate the existence of a direct link between changes in top income share and the likelihood of banking crises. Again, the primary dataset is the same as Bordo and Meissner (2012). The year-on-year change in income inequality is found to have some predictive power both in-sample and out-of-sample. Income inequality turns out to have substantial predictive power over and above credit booms and has a distinct role as a driver of financial crises that remains when controlling for credit growth. These results suggest that the empirical strategy employed by Bordo and Meissner might be unsuitable to detect the link between income inequality and banking crises.

Bellettini and Delbono (2013) were the first ones to investigate directly the "level" hypothesis to see whether persistently high levels of Gini values in income distribution relate to banking crises. The quantitative analysis is descriptive and the association seems weak, although non-negligible. They make a remark on the geography of such association (see also Atkinson and Morelli (2015, p. 49)) to stress that its assessment should be primarily focused on the crisis-originator countries (e.g., US and UK for the 2008 banking crises) where the link between growing income inequality and banking crises seems pretty robust (see, for instance, Gu and Huang, 2014).

Atkinson and Morelli (2015) test statistically both the "growth" and the "level" hypothesis relying on an updated version of their previous database (Atkinson and Morelli, 2014). The authors find no clearcut conclusion for the relationship between growing or high levels of economic inequality (summarized by different indexes) and the occurrence of banking crises in the period 2000-2012.

Perugini, Hölscher and Collie (2016) also test the "level" hypothesis by means of an econometric analysis where high levels of top income shares are shown to be robustly correlated to private sector indebtedness which in turn is a significant predictor of systemic banking risk. ${ }^{3}$ The econometric analysis is performed on a panel of 18 OECD countries for the years 1970-2007. They explicitly take into account endogeneity and reverse causation issues by using IV and GMM-sys methodology. As in Bordo and Meissner's paper, private sector credit is found to be a significant predictor of financial crises. However, it is worth stressing that Perugini, Hölscher and Collie (2016) do not investigate the presence of a direct link between income inequality and financial crises that is not explained by credit growth.

As for the choice of credit measures, Perugini, Hölscher and Collie (2016) consider both household and corporate credit, but try to control for this by including investment as a percentage of GDP. This is the same route followed by Bordo and Meissner (2012). However, notice that retained profits are also often used to finance investments, which implies that the ratio between investments and GDP may be a suboptimal proxy for credit. The main features of the above mentioned literature are summarized in Table 1 below.

\footnotetext{
${ }^{3}$ Klein (2015) detects a long-run relationship between income inequality and household debt. He uses different measures of income inequality for 9 advanced countries in the period 1953-2008 and finds that inequality and leverage are cointegrated.
} 
Table 1: Main features of some related empirical papers

\begin{tabular}{|c|c|c|c|c|c|c|c|}
\hline & $\begin{array}{l}\text { Atkinson } \\
\text { and } \\
\text { Morelli } \\
(2011)\end{array}$ & $\begin{array}{l}\text { Bordo and } \\
\text { Meissner } \\
(2012)\end{array}$ & $\begin{array}{l}\text { Bellettini } \\
\text { and Del- } \\
\text { bono } \\
(2013)\end{array}$ & $\begin{array}{l}\text { Gu and } \\
\text { Huang } \\
(2014)\end{array}$ & $\begin{array}{l}\text { Atkinson } \\
\text { and } \\
\text { Morelli } \\
(2015)\end{array}$ & $\begin{array}{l}\text { Perugini, } \\
\text { Hölscher } \\
\text { and Collie } \\
(2016)\end{array}$ & $\begin{array}{l}\text { Kirschen- } \\
\text { mann, } \\
\text { Mali- } \\
\text { nen and } \\
\text { Nyberg } \\
(2016)\end{array}$ \\
\hline Period & $1911-2010$ & $1928-2008$ & $1980-2010$ & $1928-2008$ & 1900-2012 & $1970-2007$ & $1870-2008$ \\
\hline $\begin{array}{l}\text { Number } \\
\text { of coun- } \\
\text { tries }\end{array}$ & 25 & $\begin{array}{l}14 \text { ad- } \\
\text { vanced } \\
\text { countries }\end{array}$ & 14 or 18 & $\begin{array}{l}14 \text { ad- } \\
\text { vanced } \\
\text { countries }\end{array}$ & 25 & $\begin{array}{l}18 \text { OECD } \\
\text { countries }\end{array}$ & $\begin{array}{l}14 \text { ad- } \\
\text { vanced } \\
\text { countries }\end{array}$ \\
\hline $\begin{array}{l}\text { Measure } \\
\text { of income } \\
\text { inequality }\end{array}$ & $\begin{array}{l}\text { Gini and } \\
\text { top } 1 \% \\
\text { income } \\
\text { share }\end{array}$ & $\begin{array}{l}\text { Top } 1 \% \\
\text { income } \\
\text { share }\end{array}$ & Gini & $\begin{array}{l}\text { Top } 1 \% \\
\text { income } \\
\text { share }\end{array}$ & Many & $\begin{array}{l}\text { Top in- } \\
\text { come } \\
\text { shares }\end{array}$ & $\begin{array}{l}\text { Top } 1 \% \\
\text { income } \\
\text { share }\end{array}$ \\
\hline $\begin{array}{l}\text { Growth or } \\
\text { Levels }\end{array}$ & Growth & Growth & Levels & Growth & $\begin{array}{l}\text { Growth } \\
\text { and Levels }\end{array}$ & Levels & Growth \\
\hline $\begin{array}{l}\text { Relationship } \\
\text { between } \\
\text { income } \\
\text { inequal- } \\
\text { ity and } \\
\text { banking } \\
\text { crises }\end{array}$ & Ambiguous & Ambiguous & Weak & $\begin{array}{l}\text { Strong in } \\
\text { Anglo- } \\
\text { saxon } \\
\text { countries }\end{array}$ & Ambiguous & Strong* $^{*}$ & Strong \\
\hline
\end{tabular}

\section{$3 \quad$ Data and descriptive statistics}

The dataset consists of yearly data for 33 advanced countries during the period 1970-2011. ${ }^{4}$ A description of variable definitions and sources is provided in Tables A1 and A2 in the Appendix. ${ }^{5}$ Data on the binary variable banking crisis has been compiled by Laeven and Valencia (2013). The authors define a banking crisis as an event that meets two conditions: "(1) Significant signs of financial distress in the banking system (as indicated by significant bank runs, losses in the banking system, and/or bank liquidations). (2) Significant banking policy intervention measures in response to significant losses in the banking system" (Laeven and Valencia, 2013). Our dataset includes a total of 123 country-year banking crisis observations distributed across 33 banking crisis episodes.

The income inequality measures are the Gini index and the top $1 \%$ income share before taxes and transfers. Data on the gross Gini index have been collected from the Standardized World Income Inequality

\footnotetext{
${ }^{4}$ The list of countries is: Australia, Austria, Belgium, Canada, Czech Republic, Denmark, Estonia, Finland, France, Germany, Greece, Hong Kong, Iceland, Ireland, Israel, Italy, Japan, Latvia, Lithuania, Luxembourg, Netherlands, New Zealand, Norway, Portugal, Singapore, Slovak Republic, Slovenia, South Korea, Spain, Sweden, Switzerland, United Kingdom and United States.

${ }^{5}$ The control variables shown in Tables A1 and A2 were constructed using data from the World Bank Databank, International Financial Statistics (IMF), BIS total credit statistics, Economic Freedom of the World Database (Fraser institute) and OECD.
} 
Database (SWIID) compiled by Solt (2016). The latest version of the SWIID database contains two collections of Gini indexes. The first one consists of the gross income inequality series from the Luxembourg Income Study (LIS) database. The second collection includes data from national statistical offices, cross-national income inequality databases, and academic articles (Solt, 2016).

Data for the top 1\% income share before taxes and transfers have been collected from the World Top Incomes Database (WTID) which is based on historical income tax records. Accurate information about measures such as the mean household income is necessary to compute the Gini index. These measures can be unreliable since they are based on data affected by country-dependent inconsistencies (Kirschenmann, Malinen and Nyberg, 2016). However, the top 1\% income share measure is computed using the same procedure and raw data for all countries (Piketty, 2007). In addition, data for the top $0.1 \%, 5 \%$ and $10 \%$ income shares is exploited to perform robustness tests.

Other related papers used disposable (or after tax) income to compute Gini indexes and/or top income shares. Our choice of gross incomes seems reasonable for at least three reasons. First, data on net income shares over time are currently very limited. Similarly, data on net Gini indexes are also limited relative to the gross ones. Finally, gross and net income shares tend to mimic similar developments in the distribution of income (see Malinen, 2016, p. 312, fn. 3).

Figure 1 illustrates the average gross (or market) Gini index and the top 1\% income share over the period 1970-2011 for 33 advanced countries. The general trend for both measures of income inequality is characterized by a steady increase since the 1980s.

The behavior of the average Gini index, the top $1 \%$ income share and the ratio of household credit to GDP around a banking crisis episode is illustrated in Figures 2 and 3. Figure 2 shows that the level of the Gini index (average for 27 advanced countries) is higher at the beginning of the banking crisis (vertical line) than during the previous 15 years. Moreover, the top 1\% income share (average for 14 advanced countries) is also at its peak on the eve of the crisis compared to the preceding years as shown in Figure 3.

Household credit (as a percentage of GDP) is included in these figures because the main theoretical argument used to support the connection between income inequality and banking crises is based on the expansion of household credit. The ratio of household credit to GDP (average for 21 advanced countries) almost doubles during the 15 years before the banking crisis and then falls back to its previous level once the crisis has started.

The United States is a "crisis originator" country and is an especially important case when investigating the link between income inequality and banking crises. Figures 4 and 5 display the behavior of the average Gini index, the top 1\% income share and household credit (as a percentage of GDP) around the two banking 
Figure 1: Market Gini index and top 1\% income share (average of 33 countries)

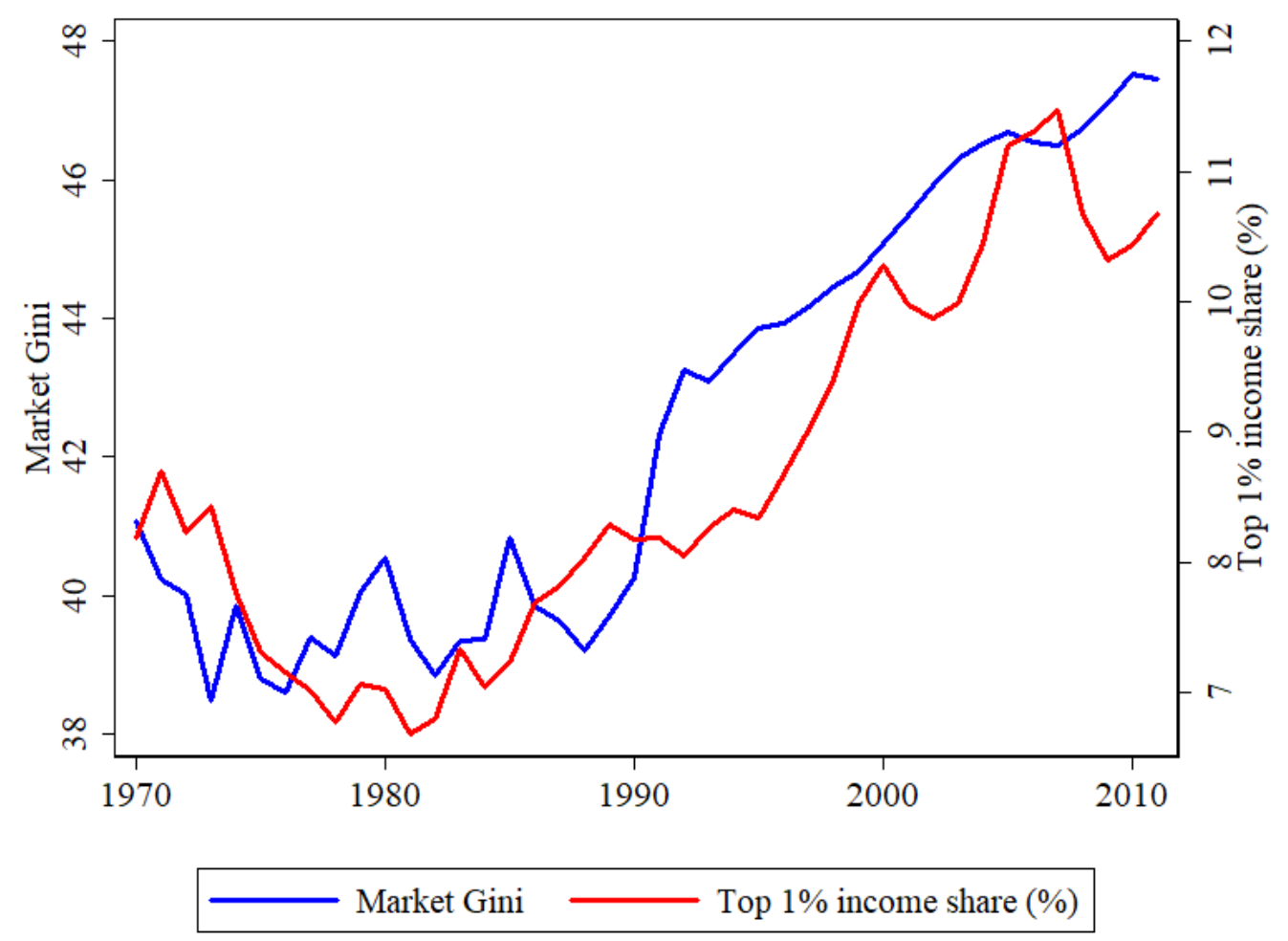

crises that started in 1988 and 2007 in the United States. ${ }^{6}$

Figure 4 shows that the Gini index was higher in the United States on the eve of the banking crisis compared to a decade earlier. Moreover, the Gini index and the ratio of household credit to GDP tend to move in tandem during the run-up to the crisis (the correlation is 0.83 ). Finally, the top $1 \%$ income share doubled during the 15 years before the crisis and then dropped once the crisis started, as shown in Figure 5. The co-movement between the top $1 \%$ income share and household credit (as a percentage of GDP) in the United States is even stronger than for the Gini index (the correlation is 0.92).

Descriptive statistics for the banking crisis variable, income inequality measures (Gini index and top income share) and the control variables are shown in Table A3 in the Appendix. It should be emphasized that data availability for the Gini index is considerably larger than for the top income share. The average value for the market Gini index is around 0.43 with a maximum of 0.58 for Hong Kong in 2002 and a minimum of 0.245 for Latvia in 1990 . The top $1 \%$ income share has a mean value of 0.09 . The highest

\footnotetext{
${ }^{6}$ The control variables shown in Tables A1 and A 2 were constructed using data from the World Bank Databank, International Financial Statistics (IMF), BIS total credit statistics, Economic Freedom of the World Database (Fraser institute) and OECD.
} 
Figure 2: Gini index and household credit (\% of GDP) around banking crisis

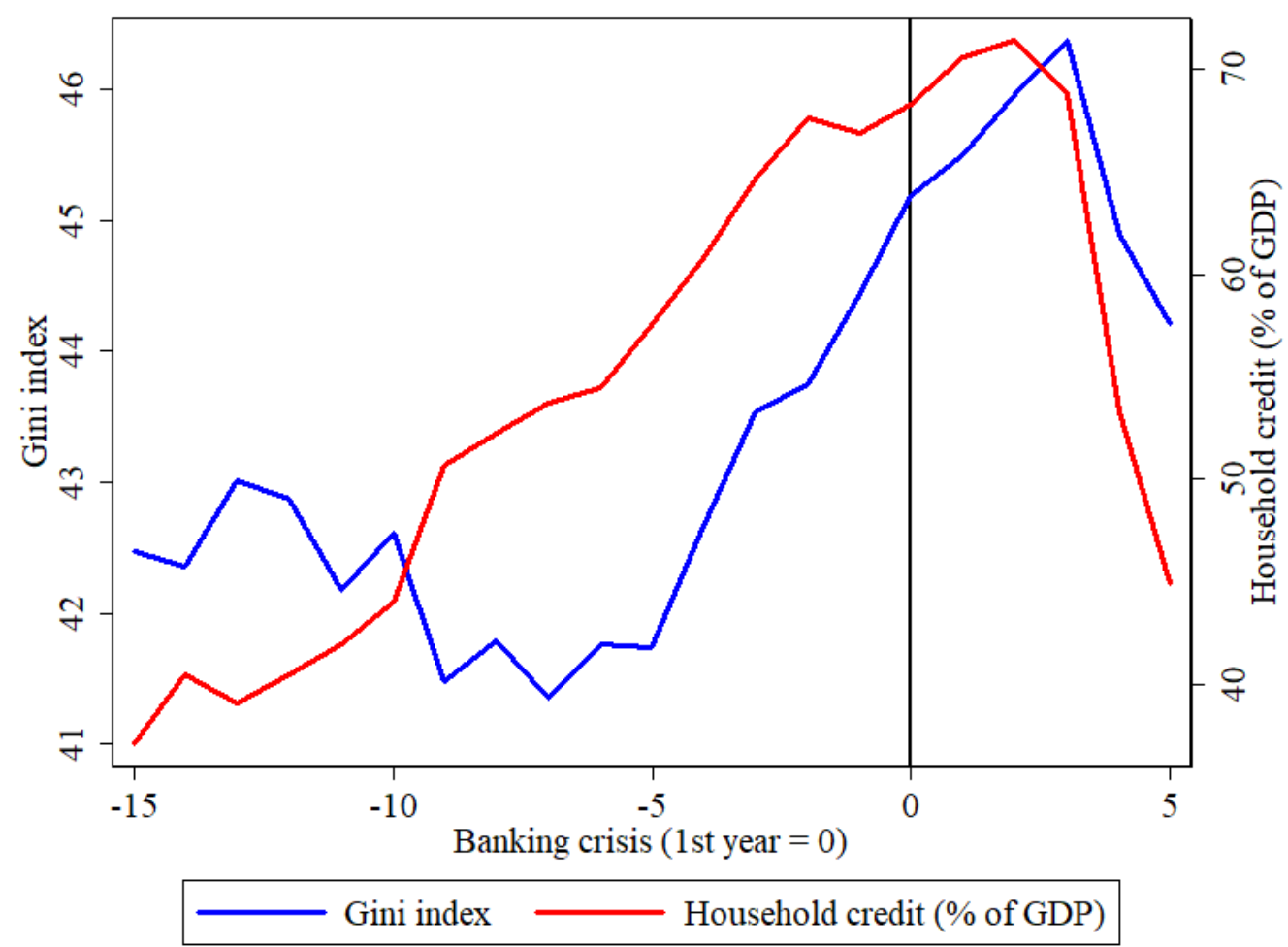

value (0.23) for the top 1 percent income share is observed in the United States in 2007, while Portugal had the lowest value (0.04) in 1981. Finally, on average around one third of all gross income goes to the top 10 percent of income earners and one fourth of this amount is earned by the top 1 percent.

\section{Empirical analysis}

The empirical approach employed in this paper follows Demigürç-Kunt and Detragiache (2005). We estimate both a baseline and an extended specification using logit regressions. For all countries and years, the binary dependent variable equals one if a banking crisis occurs and zero otherwise. The measures of income inequality level (gross Gini index and the top 1\% of gross income share) are lagged from one up to three periods to avoid simultaneity issues. The baseline and extended specifications include a set of explanatory variables that are commonly found in the literature to control for macroeconomic fundamentals, monetary conditions and the global environment. More precisely, the baseline specification includes the real growth of GDP, the change in terms of trade, depreciation of the nominal exchange rate, the real interest rate, inflation, and GDP per capita. The extended specification instead includes all control variables of the baseline model, 
Figure 3: Top 1\% income share and household credit (\% of GDP) around banking crisis

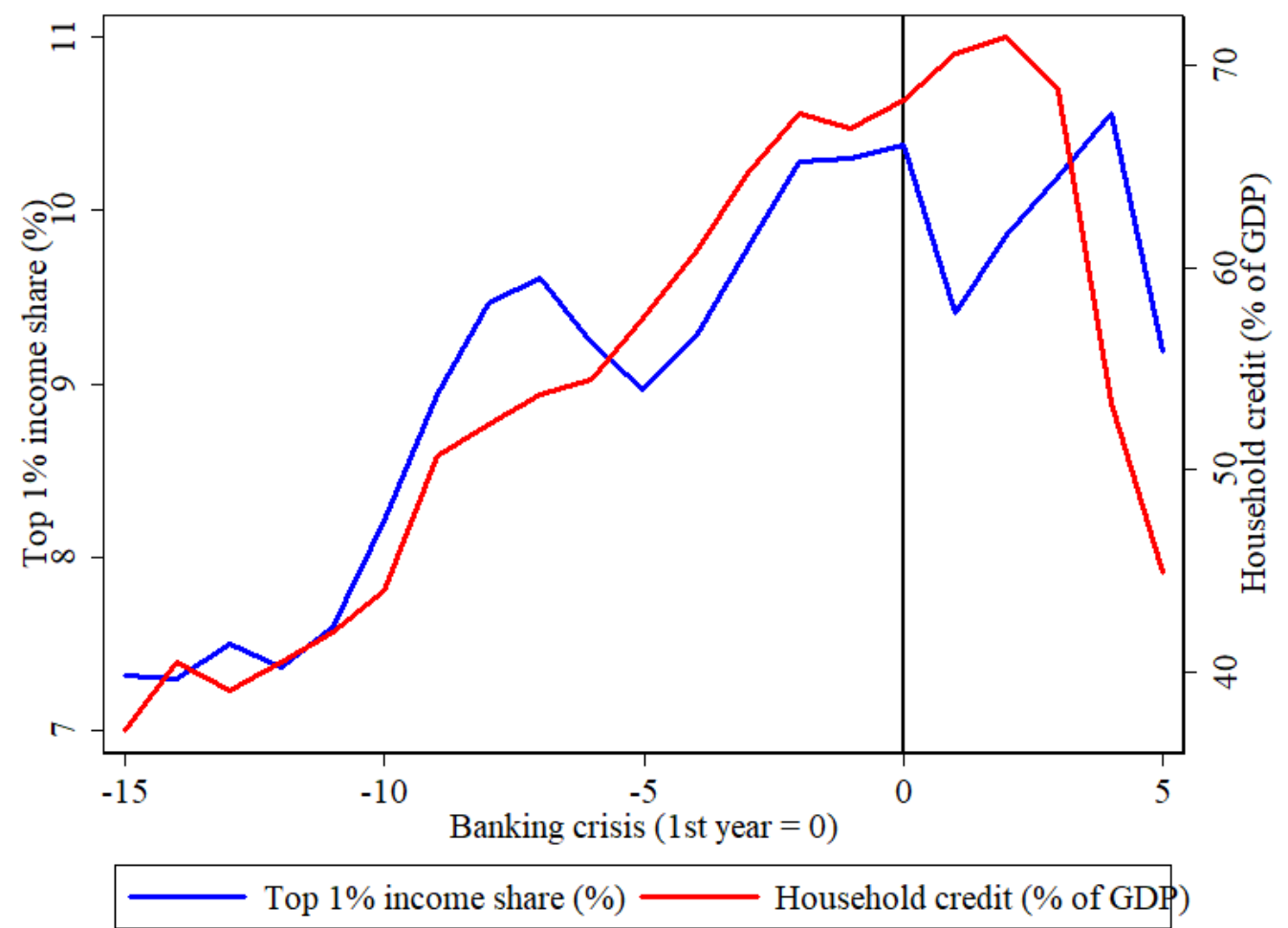

but also the ratio of broad money (M2) to international reserves, the ratio of domestic bank credit to GDP and the lagged growth rate of domestic bank credit.

The macroeconomic fundamentals are real GDP growth, inflation and nominal depreciation. A slowdown in GDP growth is likely to be associated with a banking crisis since lower economic growth negatively affects banks balance sheets by increasing the share of non-performing loans. An elevated inflation rate may be a sign of macroeconomic mismanagement which often precede banking crises (Duttagupta and Cashin, 2011).

In addition, banking crises have been found to often follow or coincide with currency crises. Consequently, nominal depreciation is employed as a proxy for high volatility in the nominal exchange rate that typically characterizes currency crises. However, even in the absence of a currency crisis, a nominal depreciation could potentially cause a banking crisis due to foreign exchange risk (Duttagupta and Cashin, 2011). Finally, GDP per capita (divided by one thousand to ease interpretation) is used as a proxy for institutional and economic development (Demigürç-Kunt and Detragiache, 2005).

Monetary conditions are proxied by the real interest rate in both the baseline and the extended specification. An increase in the real interest rate is a proxy for a tightening of financial conditions which is likely 
Figure 4: Gini index and household credit (\% of GDP) around banking crisis (USA)

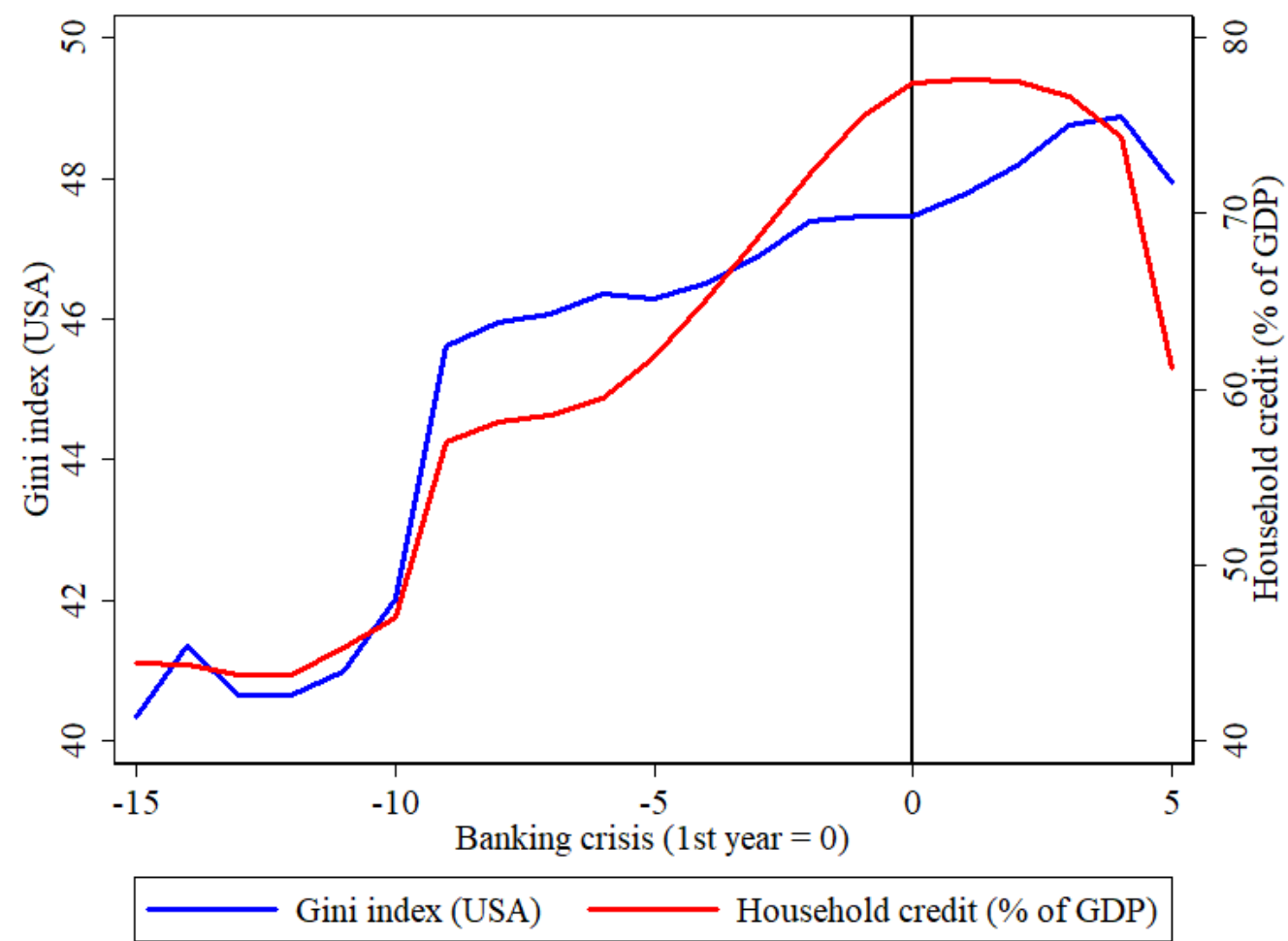

to squeeze banks balance sheets and increase the probability of a banking crisis (Duttagupta and Cashin, 2011).

The extended specification includes additional variables that are ignored in the baseline model. The ratio of private sector bank credit to GDP is used as a measure of the size of financial markets and institutions (financial deepness). Perugini, Hölscher and Collie (2016) argue that excessive levels of credit are associated with financial crises according to the literature and emphasize that the effect of stronger credit growth on the probability of financial crises depends on the level of credit to GDP. The lagged growth rate of real domestic credit is included as a proxy for credit booms that often precede banking crises (Schularick and Taylor, 2012).

Another variable, added to the extended specification, is the ratio of broad money (M2) to foreign exchange reserves. This variable measures a countrys vulnerability to currency crises which often coincide with banking crises. This variable was divided by one thousand to ease interpretation.

The global environment is proxied by the change in terms of trade in both the baseline and the extended specification. This variable has been divided by one trillion to ease interpretation of the coefficient. The 
Figure 5: Top 1\% income share and household credit (\% of GDP) around banking crisis (USA)

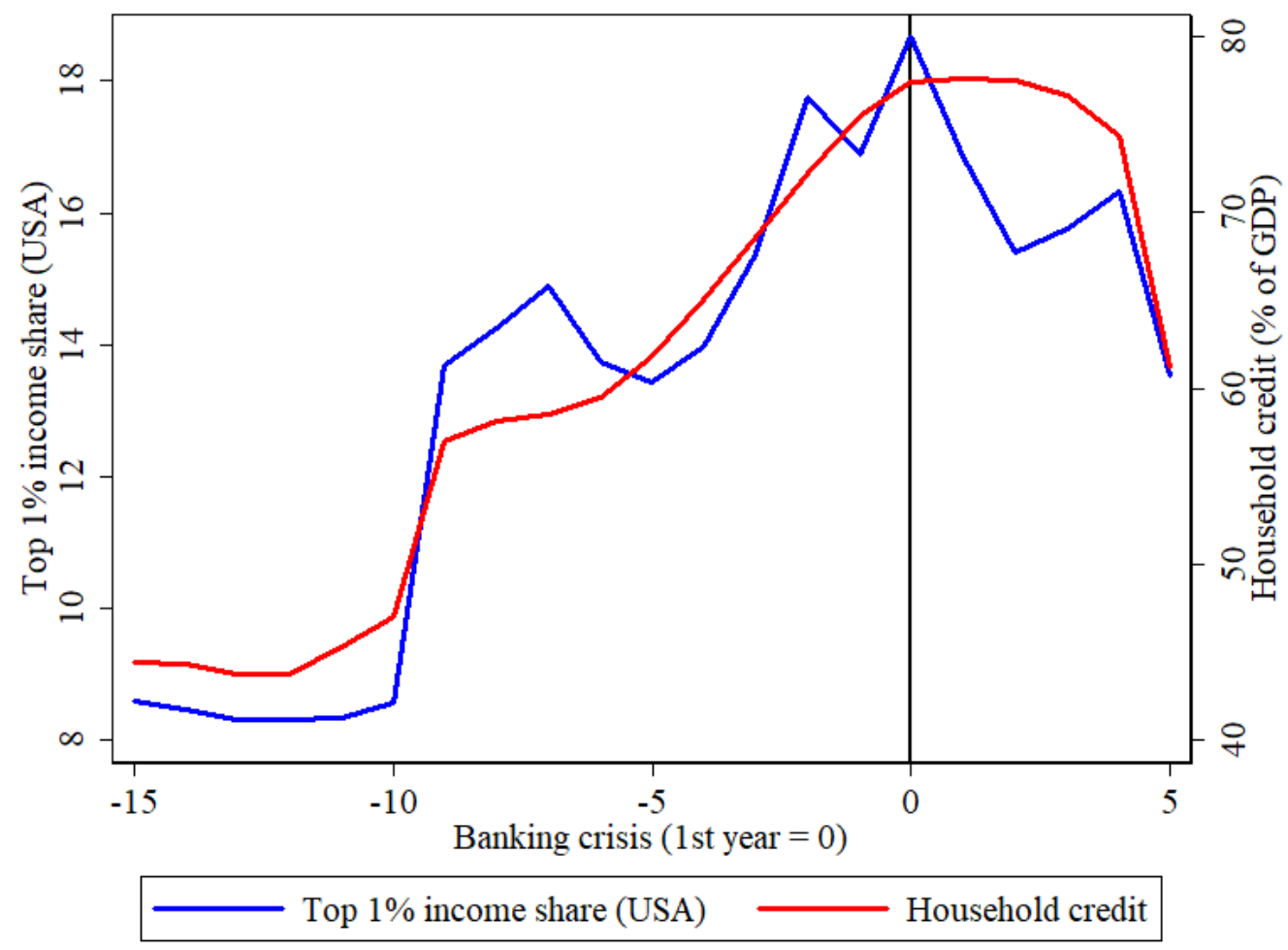

change in terms of trade is likely to affect GDP growth and consequently the stability of the banking sector (Duttagupta and Cashin, 2011). Finally, the occurrence of a crisis is likely to affect the future path of the explanatory variables, which would generate endogeneity issues. To mitigate this problem, five observations are dropped after the first year of crisis, which implies that all crisis observations except the first year are dropped. In addition, White-Huber robust standard errors clustered by country are used throughout the paper except for the results presented in Tables A12-A13.

\subsection{The statistical model}

The main purpose of this paper is to investigate whether the level of income inequality is associated with the occurrence of banking crises. To this end, we model the probability of a banking crisis using a multivariate logit model. Formally, let $y_{i t}$ be a binary variable equal to 1 if a banking crisis occurs in country $i$ during year $t$, and 0 otherwise, and let $x_{i t}$ be a vector of $K$ explanatory variables. We assume that the probability of observing a crisis depends on $x_{i t}$ through the following expression:

$$
\operatorname{Prob}\left(y_{i t}=1 \mid x_{i t}\right)=\pi_{i t}(\beta)=\frac{1}{1+\exp \left(-x_{i t}^{\prime} \beta\right)},
$$


where $\beta$ is a vector of $K$ unknown parameters to be estimated. The nonlinearity of the this expression implies that, contrary to the linear regression model, the parameters $\beta$ do not measure the effect on the probability of a crisis of a change in one of the explanatory variables. Indeed, it is easy to check that for a continuous explanatory variable $x_{k, i t}$ the marginal effect on the probability of a crisis is given by:

$$
\frac{\partial \operatorname{Prob}\left(y_{i t}=1 \mid x_{i t}\right)}{\partial x_{k, i t}}=\pi_{i t}(\beta)\left[1-\pi_{i t}(\beta)\right] \beta_{k},
$$

where $\beta_{k}$ is the coefficient that multiplies $x_{k, i t}$ in the definition of $\pi_{i t}(\beta)$. Thus, unlike the linear regression model, the marginal effect of a change in one of the regressors varies across the observations, and depends on the original probabilities $\pi_{i t}(\beta)$. In particular, the effect is shrunk to zero if the occurrence of a crisis is either extremely unlikely $\left(\pi_{i t}(\beta) \approx 0\right)$ or extremely likely $\left(\pi_{i t}(\beta) \approx 1\right)$, and will be highest for values of $\pi_{i t}(\beta)$ close to 0.5 . Note however that $\beta_{k}$ is informative on the sign of the marginal effect, as the shrinking coefficient $\pi_{i t}(\beta)\left[1-\pi_{i t}(\beta)\right]$ is positive by construction.

Given a sample of observations $\left\{\left(y_{i t}, x_{i t}\right), t=1,2, \ldots, T, i=1,2, \ldots, N_{t}\right\}$, the unknown parameters $\beta$ can be estimated by maximizing the sample loglikelihood function of the model:

$$
\log L(\beta)=\sum_{t=1}^{T} \sum_{i=1}^{N_{t}}\left[y_{i t} \log \pi_{i t}(\beta)+\left(1-y_{i t}\right) \log \left(1-\pi_{i t}(\beta)\right)\right] .
$$

Under suitable regularity conditions, and when the sample size grows to infinity, the resulting Maximum Likelihood Estimator converges to the true value of $\beta$ and is normally distributed. In samples of finite size, its distribution will only be approximately Gaussian. Its variance matrix is readily provided by any econometric package.

\subsection{Results}

If a higher level of gross income inequality is associated with the occurrence of banking crises, we would expect the coefficients of the lagged Gini index to be positive and significant. The results displayed in Table 2 show that the coefficients of the Gini index have the expected positive sign and are statistically significant at the 1 percent level. Moreover, the Gini coefficients are positive and highly significant for all lags in both the baseline and the extended model. Consequently, the significance of the Gini index is not sensitive to the specific choice of the number of lags or to the inclusion of measures of the level and growth rate of domestic credit to the private sector.

The baseline estimation for the Gini index covers 33 countries and 24 crisis episodes for the period 19702011. Due to data limitations for domestic credit and the ratio of M2 to international reserves, the extended estimation includes 28 countries and 20 crisis episodes for the same period. 
Table 2: Results for logit estimations with Gini index, period 1970-2011

\begin{tabular}{|c|c|c|c|c|c|c|}
\hline Variables & $\begin{array}{l}(1) \\
\text { crisis }\end{array}$ & $\begin{array}{c}(2) \\
\text { crisis }\end{array}$ & $\begin{array}{c}(3) \\
\text { crisis }\end{array}$ & $\begin{array}{l}(4) \\
\text { crisis }\end{array}$ & $\begin{array}{c}(5) \\
\text { crisis }\end{array}$ & $\begin{array}{c}(6) \\
\text { crisis }\end{array}$ \\
\hline gdp_growth & $\begin{array}{c}-0.181^{* * *} \\
(0.0515)\end{array}$ & $\begin{array}{c}-0.177^{* * *} \\
(0.0514)\end{array}$ & $\begin{array}{c}-0.177^{* * *} \\
(0.0507)\end{array}$ & $\begin{array}{c}-0.265^{* * *} \\
(0.0620)\end{array}$ & $\begin{array}{c}-0.274^{* * *} \\
(0.0613)\end{array}$ & $\begin{array}{c}-0.257^{* * *} \\
(0.0630)\end{array}$ \\
\hline totchange & $\begin{array}{c}0.0622^{* * *} \\
(0.0131)\end{array}$ & $\begin{array}{c}0.0613^{* * *} \\
(0.0130)\end{array}$ & $\begin{array}{c}0.0565^{* * *} \\
(0.0125)\end{array}$ & $\begin{array}{c}0.0845^{* * *} \\
(0.0211)\end{array}$ & $\begin{array}{c}0.0858^{* * *} \\
(0.0204)\end{array}$ & $\begin{array}{c}0.0813^{* * *} \\
(0.0190)\end{array}$ \\
\hline depreciation & $\begin{array}{c}-0.0739^{* * *} \\
(0.0154)\end{array}$ & $\begin{array}{c}-0.0738^{* * *} \\
(0.0155)\end{array}$ & $\begin{array}{c}-0.0736^{* * *} \\
(0.0155)\end{array}$ & $\begin{array}{c}-0.0885^{* * *} \\
(0.0196)\end{array}$ & $\begin{array}{c}-0.0884^{* * *} \\
(0.0206)\end{array}$ & $\begin{array}{c}-0.0873^{* * *} \\
(0.0214)\end{array}$ \\
\hline realinterest & $\begin{array}{c}0.0306 \\
(0.0743)\end{array}$ & $\begin{array}{c}0.0416 \\
(0.0752)\end{array}$ & $\begin{array}{c}0.0372 \\
(0.0724)\end{array}$ & $\begin{array}{l}0.0616 \\
(0.115)\end{array}$ & $\begin{array}{l}0.0660 \\
(0.119)\end{array}$ & $\begin{array}{l}0.0488 \\
(0.130)\end{array}$ \\
\hline inflation & $\begin{array}{c}0.0664 \\
(0.0621)\end{array}$ & $\begin{array}{c}0.0743 \\
(0.0624)\end{array}$ & $\begin{array}{c}0.0734 \\
(0.0597)\end{array}$ & $\begin{array}{c}0.0311 \\
(0.0574)\end{array}$ & $\begin{array}{c}0.0360 \\
(0.0557)\end{array}$ & $\begin{array}{c}0.0116 \\
(0.0594)\end{array}$ \\
\hline gdp_pc & $\begin{array}{c}0.0293^{* * *} \\
(0.00856)\end{array}$ & $\begin{array}{c}0.0295^{* * *} \\
(0.00878)\end{array}$ & $\begin{array}{c}0.0285^{* * *} \\
(0.00897)\end{array}$ & $\begin{array}{c}0.0500^{* * *} * \\
(0.0115)\end{array}$ & $\begin{array}{c}0.0507 * * * \\
(0.0121)\end{array}$ & $\begin{array}{c}0.0508^{* * *} * \\
(0.0122)\end{array}$ \\
\hline m2_reserves & & & & $\begin{array}{c}0.0107 \\
(0.0139)\end{array}$ & $\begin{array}{c}0.0107 \\
(0.0146)\end{array}$ & $\begin{array}{c}0.0101 \\
(0.0156)\end{array}$ \\
\hline credit_gdp & & & & $\begin{array}{c}0.0123^{* *} \\
(0.00505)\end{array}$ & $\begin{array}{c}0.0130^{* *} \\
(0.00533)\end{array}$ & $\begin{array}{c}0.0120^{* *} \\
(0.00549)\end{array}$ \\
\hline L2.credit_growth & & & & $\begin{array}{c}0.0175 \\
(0.0218)\end{array}$ & $\begin{array}{c}0.0162 \\
(0.0230)\end{array}$ & $\begin{array}{c}1.622 \\
(2.552)\end{array}$ \\
\hline L.gini_market & $\begin{array}{c}0.118^{* * *} \\
(0.0390)\end{array}$ & & & $\begin{array}{c}0.180^{* * *} \\
(0.0586)\end{array}$ & & \\
\hline L2.gini_market & & $\begin{array}{c}0.118^{* * *} \\
(0.0383)\end{array}$ & & & $\begin{array}{c}0.188^{* * *} \\
(0.0574)\end{array}$ & \\
\hline L3.gini_market & & & $\begin{array}{c}0.106^{* * *} \\
(0.0379)\end{array}$ & & & $\begin{array}{c}0.180^{* * *} \\
(0.0550)\end{array}$ \\
\hline Observations & 588 & 575 & 566 & 417 & 413 & 406 \\
\hline No. crises & 24 & 24 & 24 & 20 & 20 & 20 \\
\hline \% Total Correct & 96.09 & 95.83 & 95.94 & 96.40 & 96.13 & 96.06 \\
\hline \% Crises Correct & 8.333 & 8.333 & 8.333 & 25 & 20 & 20 \\
\hline$\%$ No-Crises Correct & 99.82 & 99.64 & 99.82 & 100 & 100 & 100 \\
\hline Pseudo R-sq & 0.178 & 0.178 & 0.175 & 0.275 & 0.277 & 0.276 \\
\hline Chi-sq & 35.72 & 35.44 & 34.75 & 44.16 & 44.28 & 43.96 \\
\hline $\mathrm{p}$-value & $8.20 \mathrm{e}-06$ & $9.22 \mathrm{e}-06$ & $1.25 \mathrm{e}-05$ & $3.08 \mathrm{e}-06$ & $2.93 \mathrm{e}-06$ & $3.35 \mathrm{e}-06$ \\
\hline AIC & 180.8 & 180 & 179.9 & 138.4 & 137.8 & 137.5 \\
\hline
\end{tabular}

Robust standard errors in parentheses.

$* * * \mathrm{p}<0.01,{ }^{* *} \mathrm{p}<0.05, * \mathrm{p}<0.1$

The Gini index is a useful measure of total income inequality in a country, but it can be integrated with additional information. To this end, we can use the top 1\% income share (before taxes and transfers) similarly to Atkinson and Morelli (2015).

Table 3 shows the results for the baseline and extended estimations with the top $1 \%$ income share. The coefficient multiplying the top $1 \%$ income share is positive and significant at the $1 \%$ and $5 \%$ level for the 
Table 3: Results for logit estimation with top 1\% income share, period 1970-2011

\begin{tabular}{|c|c|c|c|c|c|c|}
\hline Variables & $\begin{array}{c}(1) \\
\text { crisis }\end{array}$ & $\begin{array}{c}(2) \\
\text { crisis }\end{array}$ & $\begin{array}{l}(3) \\
\text { crisis }\end{array}$ & $\begin{array}{l}(4) \\
\text { crisis }\end{array}$ & $\begin{array}{l}(5) \\
\text { crisis }\end{array}$ & $\begin{array}{c}(6) \\
\text { crisis }\end{array}$ \\
\hline gdp_growth & $\begin{array}{c}-0.308^{* * *} \\
(0.105)\end{array}$ & $\begin{array}{c}-0.291^{* * *} \\
(0.107)\end{array}$ & $\begin{array}{c}-0.312^{* * *} \\
(0.0955)\end{array}$ & $\begin{array}{c}-0.275^{* * *} \\
(0.0913)\end{array}$ & $\begin{array}{c}-0.239^{* *} \\
(0.101)\end{array}$ & $\begin{array}{c}-0.264^{* * *} \\
(0.0833)\end{array}$ \\
\hline totchange & $\begin{array}{c}0.0630^{* * *} \\
(0.0128)\end{array}$ & $\begin{array}{c}0.0665^{* * *} \\
(0.0125)\end{array}$ & $\begin{array}{c}0.0198 \\
(0.0169)\end{array}$ & $\begin{array}{c}0.0583^{* * *} * \\
(0.0108)\end{array}$ & $\begin{array}{c}0.0651^{* * *} \\
(0.0119)\end{array}$ & $\begin{array}{c}0.0308 \\
(0.0197)\end{array}$ \\
\hline depreciation & $\begin{array}{c}-0.0689^{* * *} \\
(0.0176)\end{array}$ & $\begin{array}{c}-0.0741^{* * *} \\
(0.0156)\end{array}$ & $\begin{array}{c}-0.0588^{* * *} * \\
(0.0165)\end{array}$ & $\begin{array}{c}-0.0727^{* * *} \\
(0.0224)\end{array}$ & $\begin{array}{c}-0.0813^{* * *} \\
(0.0220)\end{array}$ & $\begin{array}{c}-0.0670^{* * * *} \\
(0.0254)\end{array}$ \\
\hline realinterest & $\begin{array}{c}0.0823 \\
(0.0684)\end{array}$ & $\begin{array}{c}0.0839 \\
(0.0762)\end{array}$ & $\begin{array}{c}0.0148 \\
(0.0767)\end{array}$ & $\begin{array}{c}0.155 \\
(0.0998)\end{array}$ & $\begin{array}{c}0.172 \\
(0.124)\end{array}$ & $\begin{array}{l}0.0804 \\
(0.142)\end{array}$ \\
\hline inflation & $\begin{array}{c}-0.0692 \\
(0.0761)\end{array}$ & $\begin{array}{l}-0.0651 \\
(0.0790)\end{array}$ & $\begin{array}{c}-0.125^{*} \\
(0.0749)\end{array}$ & $\begin{array}{c}0.0233 \\
(0.0863)\end{array}$ & $\begin{array}{c}0.0359 \\
(0.109)\end{array}$ & $\begin{array}{c}-0.0405 \\
(0.117)\end{array}$ \\
\hline gdp_pc & $\begin{array}{c}0.0369^{* * *} \\
(0.0137)\end{array}$ & $\begin{array}{c}0.0379^{* * *} \\
(0.0137)\end{array}$ & $\begin{array}{l}0.0241^{*} \\
(0.0123)\end{array}$ & $\begin{array}{c}0.0426^{* * *} \\
(0.0117)\end{array}$ & $\begin{array}{c}0.0473^{* * *} \\
(0.0120)\end{array}$ & $\begin{array}{c}0.0330^{* * *} \\
(0.0111)\end{array}$ \\
\hline m2_reserves & & & & $\begin{array}{c}0.00229 \\
(0.0101)\end{array}$ & $\begin{array}{c}-0.00249 \\
(0.0196)\end{array}$ & $\begin{array}{c}0.000922 \\
(0.0110)\end{array}$ \\
\hline credit_gdp & & & & $\begin{array}{c}0.0159^{*} \\
(0.00826)\end{array}$ & $\begin{array}{c}0.0163^{*} \\
(0.00912)\end{array}$ & $\begin{array}{c}0.0129 * \\
(0.00776)\end{array}$ \\
\hline L2.credit_growth & & & & $\begin{array}{c}-0.00640 \\
(0.0198)\end{array}$ & $\begin{array}{c}-0.00698 \\
(0.0229)\end{array}$ & $\begin{array}{c}3.298 \\
(4.457)\end{array}$ \\
\hline L.topincomep99 & $\begin{array}{c}12.82^{* * *} \\
(4.289)\end{array}$ & & & $\begin{array}{c}19.55^{* * *} \\
(7.405)\end{array}$ & & \\
\hline L2.topincomep99 & & $\begin{array}{c}13.30^{* * *} \\
(4.536)\end{array}$ & & & $\begin{array}{c}21.12^{* *} \\
(8.334)\end{array}$ & \\
\hline L3.topincomep99 & & & $\begin{array}{c}4.077 \\
(5.271)\end{array}$ & & & $\begin{array}{l}12.10^{*} \\
(7.175)\end{array}$ \\
\hline Observations & 408 & 402 & 392 & 324 & 321 & 317 \\
\hline No. crises & 15 & 15 & 15 & 14 & 14 & 14 \\
\hline \% Total Correct & 96.57 & 96.52 & 96.17 & 96.30 & 96.26 & 95.90 \\
\hline \% Crises Correct & 6.667 & 6.667 & 0 & 14.29 & 14.29 & 7.143 \\
\hline$\%$ No-Crises Correct & 100 & 100 & 100 & 100 & 100 & 100 \\
\hline Pseudo R-sq & 0.195 & 0.202 & 0.145 & 0.223 & 0.238 & 0.178 \\
\hline Chi-sq & 25.04 & 25.82 & 18.43 & 25.74 & 27.40 & 20.37 \\
\hline $\mathrm{p}$-value & 0.000748 & 0.000542 & 0.0102 & 0.00411 & 0.00225 & 0.0260 \\
\hline AIC & 119.5 & 118.3 & 124.9 & 111.6 & 109.7 & 116.4 \\
\hline
\end{tabular}

Robust standard errors in parentheses.

${ }^{* * *} \mathrm{p}<0.01,{ }^{* *} \mathrm{p}<0.05,{ }^{*} \mathrm{p}<0.1$

first and second. However, the top $1 \%$ income share is not significant at lag three in the baseline model, and is only significant at the $10 \%$ level in the extended model.

Overall, these results suggest that a higher level of the top $1 \%$ income share is associated with a higher probability of banking crises. This finding reinforces the results found for the Gini index, even though statistical significance is generally weaker for the top $1 \%$ income share. The baseline model estimation is 
based on a sample containing 15 banking crises in 19 countries, while the sample used to estimate the extended model contains 14 banking crises distributed across 18 countries. Turning the attention to macroeconomic fundamentals, we note that the coefficient of contemporaneous real GDP growth is negative and highly significant in all estimations. This finding is consistent with Demigürç-Kunt and Detragiache (2005) and suggests that lower GDP growth precede or coincide with the onset of banking crises. In addition, the coefficient of GDP per capita is positive and significant.

The estimate of the inflation rate coefficient is positive but insignificant in Table 2, and insignificant with a fluctuating sign in Table 6; this is different from Demigürç-Kunt and Detragiache (2005), who find the inflation rate coefficient to be positive and significant for 94 advanced and developing countries. It should be emphasized that our paper only includes advanced countries for which the volatility of the inflation rate is typically lower than for developing countries. Finally, the coefficient of nominal depreciation is found to be negative and highly significant in all specifications.

Concerning monetary conditions, the real interest rate has a positive but insignificant coefficient in all estimations reported in Tables 2 and 3. Furthermore, the estimates of the credit to GDP coefficient is positive and significant in all specifications. This result is in line with the findings in Perugini, Hölscher and Collie (2016).

Among the global conditions, the coefficient of the change in terms of trade is estimated to be positive and highly significant. Finally, the coefficient for the ratio of broad money (M2) to foreign exchange reserves is insignificant in all estimations.

The results above clearly show that a higher level of income inequality is associated with a higher probability of a banking crisis occurrence. The question is, how large is the effect of the level of income inequality on the probability of a banking crisis. We follow the approach by Kirschenmann, Malinen and Nyberg (2016) and calculate the average marginal effects for the Gini index and the top 1\% income share.

Table 4 shows the average marginal effects of the Gini index and the top 1\% income share for columns 1 and 4 in Tables 2 and 3. The average level of the Gini index for the extended model and the full sample has a standard deviation of about 5.87. An increase in the level of the Gini index (lagged 1 period) by one standard deviation raises the likelihood of a banking crisis by 3.81 percentage points. An increase in the probability of a banking crisis by 3.81 percentage points is economically a large effect given that the frequency of a crisis episode is only 4.8 percent in the full sample.

Furthermore, the standard deviation is around 0.03 for the average level of the top $1 \%$ income share in the extended model for the full sample, meaning that an increase of one standard deviation in the level of the top $1 \%$ income share raises the probability of a banking crisis by 2.21 percentage points (the frequency of a crisis is $4.3 \%$ in this sample). 
Table 4: Average marginal effects of Gini index and top 1\% income share

\begin{tabular}{lcccccc}
\hline \hline & & Baseline & & \multicolumn{3}{c}{ Extension } \\
Variable & Full sample & $>50 \%$ & $>75 \%$ & Full sample & $>50 \%$ & $>75 \%$ \\
\hline L1.Gini & $0.0041^{* * *}$ & $0.0058^{*}$ & $0.0131^{* * *}$ & $0.0065^{* * *}$ & $0.0120^{* *}$ & $0.0171^{* * *}$ \\
& $(0.0014)$ & $(0.0030)$ & $(0.0041)$ & $(0.0022)$ & $(0.0047)$ & $(0.0055)$ \\
Observations & 588 & 316 & 168 & 417 & 223 & 117 \\
Countries & 33 & 31 & 25 & 28 & 25 & 18 \\
Crises & 24 & 16 & 11 & 20 & 14 & 10 \\
Std. Dev. & 3.1269 & 1.5216 & 1.2988 & 3.0268 & 1.3066 & 1.0691 \\
\hline L1. Top 1\% income & $0.4038^{* * *}$ & $0.6073^{* * *}$ & $0.7452^{* * *}$ & $0.6888^{* * *}$ & $1.4458^{* * *}$ & $2.0375^{* *}$ \\
& $(0.1534)$ & $(0.2050)$ & $(0.2476)$ & $(0.2610)$ & $(0.3452)$ & $(0.9283)$ \\
Observations & 408 & 210 & 119 & 324 & 172 & 95 \\
Countries & 19 & 16 & 14 & 18 & 16 & 13 \\
Crises & 15 & 8 & 5 & 14 & 8 & 4 \\
Std. Dev. & 0.0190 & 0.0170 & 0.0157 & 0.0191 & 0.0179 & 0.0160 \\
\hline \hline
\end{tabular}

Robust standard errors in parentheses.

$* * * \mathrm{p}<0.01,{ }^{* *} \mathrm{p}<0.05,{ }^{*} \mathrm{p}<0.1$

It could be of interest to examine whether an increase in the level of income inequality depends on the initial level of inequality. The 50th and 75 th percentile for the Gini index and the top $1 \%$ income share are computed based on the full sample in the baseline and extended specification respectively. The standard deviation is around 3.9 for the Gini index for countries above the 75 th percentile in the extended model. An increase of one standard deviation in the level of the Gini index for countries above the 75th percentile increases the probability of a crisis by 6.60 percentage points. Consequently, the effect of an increase in the level of income inequality on the likelihood of crisis is higher if the country already has a high level of income inequality.

To conclude, the results show that the level of income inequality before taxes and transfers is positively and significantly associated with banking crises. Moreover, the effect of an increase in the level of income inequality on the probability of occurrence of a banking crisis is relatively large in economic terms. Finally, the results suggest that an increase in the level of income inequality has a bigger effect on the probability of banking crises if the country already has an high level of income inequality.

\subsection{Robustness and sensitivity analysis}

We now estimate a set of different specifications to test the robustness of the results illustrated in the previous section. The first issue we consider is whether the results still hold when models include country fixed effects. One way to check if this is the case amounts to estimating logit regressions with country fixed effects. However, this procedure implies that the number of available observations in the specifications shown 
in Tables 2 and 3 drop by at least one third.

Consequently, we include macro-region fixed effects, following Magud and Vesperoni (2015) and Hutchinson (2002). These dummy variables control for region-specific unobservable time-invariant characteristics, and are essentially equivalent to an aggregated form of fixed effects analysis (Magud and Vesperoni, 2015). Accordingly, the 33 advanced countries in the dataset were divided in six different geographic regions. ${ }^{7}$

Table 5 shows the estimation results of the baseline and extended specifications including regional dummy variables and the Gini index. In the baseline model, the Gini coefficient has the expected sign and is significant at the $10 \%$ level for the first and second lag of the Gini index. In comparison to the specifications without regional dummies, the third lag of the Gini index is no longer significant. All lags of the Gini coefficient are significant at the $5 \%$ level in the extended specification. Finally, the coefficient for the top $1 \%$ income share is significant at the $1 \%$ level in both the baseline and extended estimations shown in Table 6 .

Similarly to Magud and Vesperoni (2015) as well as Bordo and Meissner (2012), we include yearly dummy variables to control for unobservable time effects. In the Appendix we show the results for the Gini index and top $1 \%$ income share including both region- and decade- $(1980 \mathrm{~s}, 1990 \mathrm{~s}$ and 2000s) fixed effects. The estimated coefficient of the Gini index is insignificant for all lags in the baseline specification in Table A4 in the Appendix. However, the estimated Gini coefficients are positive and significant at the $10 \%$ level in the extended model. Moreover, the coefficient for the top $1 \%$ income share is generally highly significant in both the baseline and extended model shown in Table A5.

Furthermore, to test the robustness of the results for the top $1 \%$ income share, we re-estimate the baseline and extended specification for the top $0.1 \%, 5 \%$ and $10 \%$ income shares, including regional fixed effects. Table A6 in the Appendix shows that the coefficients for top $0.1 \%, 5 \%$ and $10 \%$ income shares are positive and highly significant.

To test whether the significance of the results depends on a specific region, we estimate the extended model with one lag for the Gini index and the top $1 \%$ income share excluding one region at a time. The Gini index is significant when excluding any of the six different regions shown in Table A7. However, the results are only significant at the $10 \%$ level when excluding North America and Australasia or Western Europe. Moreover, the coefficient for the top $1 \%$ income share is significant under the exclusion of any region with the exception of North America and Australasia or Western Europe, as shown in Table A8.

Bordo and Meissner (2012) argue that domestic bank credit may not be a a good proxy for total credit if substantial amounts of credit are provided by non-bank institutions. For example, in the United States

\footnotetext{
${ }^{7}$ The 33 countries are divided into the following 6 regions: North America and Australasia (Australia, Canada, New Zealand and the United States), South Europe (Israel, Italy, Portugal and Spain), East and Southeast Europe (Czech Republic, Estonia, Greece, Latvia, Lithuania, Slovak Republic and Slovenia), Nordic countries (Denmark, Finland, Iceland, Norway and Sweden), Asia (Hong Kong, Japan, South Korea, and Singapore) and Western Europe (Austria, Belgium, France, Germany, Ireland, Luxembourg, Netherlands, Switzerland and the United Kingdom).
} 
Table 5: Results for Gini index including regional dummies

\begin{tabular}{|c|c|c|c|c|c|c|}
\hline & (1) & $(2)$ & $(3)$ & (4) & $(5)$ & (6) \\
\hline Variables & crisis & crisis & crisis & crisis & crisis & crisis \\
\hline \multirow[t]{2}{*}{ gdp_growth } & $-0.172^{* * *}$ & $-0.170^{* * *}$ & $-0.171^{* * *}$ & $-0.371^{* * *}$ & $-0.386^{* * *}$ & $-0.390^{* * *}$ \\
\hline & $(0.0593)$ & $(0.0596)$ & $(0.0597)$ & $(0.0774)$ & $(0.0785)$ & $(0.0809)$ \\
\hline \multirow[t]{2}{*}{ totchange } & $0.0721^{* * *}$ & $0.0721^{* * *}$ & $0.0689^{* * *}$ & $0.123^{* * *}$ & $0.129^{* * *}$ & $0.128^{* * *}$ \\
\hline & $(0.0160)$ & $(0.0163)$ & $(0.0156)$ & $(0.0295)$ & $(0.0300)$ & $(0.0291)$ \\
\hline \multirow[t]{2}{*}{ depreciation } & $-0.0695^{* * *}$ & $-0.0688^{* * *}$ & $-0.0689 * * *$ & $-0.0806^{* * *}$ & $-0.0799 * * *$ & $-0.0782^{* * *}$ \\
\hline & $(0.0153)$ & $(0.0153)$ & $(0.0154)$ & $(0.0186)$ & $(0.0192)$ & $(0.0212)$ \\
\hline \multirow[t]{2}{*}{ realinterest } & 0.0391 & 0.0494 & 0.0463 & 0.123 & 0.127 & 0.0865 \\
\hline & $(0.0843)$ & $(0.0863)$ & $(0.0861)$ & $(0.112)$ & $(0.117)$ & $(0.148)$ \\
\hline \multirow[t]{2}{*}{ inflation } & 0.0624 & 0.0700 & 0.0705 & 0.0356 & 0.0438 & 0.00360 \\
\hline & $(0.0692)$ & $(0.0695)$ & $(0.0675)$ & $(0.0795)$ & $(0.0803)$ & $(0.0732)$ \\
\hline \multirow[t]{2}{*}{ gdp_pc } & $0.0308^{* * *}$ & $0.0308 * * *$ & $0.0301 * * *$ & $0.0592^{* * *}$ & $0.0613^{* * *}$ & $0.0637 * * *$ \\
\hline & $(0.0107)$ & $(0.0106)$ & $(0.0104)$ & $(0.0182)$ & $(0.0195)$ & $(0.0208)$ \\
\hline \multirow[t]{2}{*}{ d_NA_Australasia } & -1.055 & -1.047 & -1.075 & -0.535 & -0.508 & -0.580 \\
\hline & $(0.968)$ & $(0.973)$ & $(0.977)$ & $(1.029)$ & $(1.033)$ & $(0.955)$ \\
\hline \multirow[t]{2}{*}{ d_South_Europe } & 0.364 & 0.365 & 0.355 & $0.718^{* *}$ & $0.760^{* *}$ & 0.615 \\
\hline & $(0.485)$ & $(0.501)$ & $(0.489)$ & $(0.364)$ & $(0.379)$ & $(0.488)$ \\
\hline \multirow[t]{2}{*}{ d_East_Europe } & 0.317 & 0.285 & 0.260 & - & - & - \\
\hline & $(0.964)$ & $(0.994)$ & $(1.001)$ & $(-)$ & $(-)$ & $(-)$ \\
\hline \multirow[t]{2}{*}{ d_Nordic } & -0.669 & -0.642 & -0.706 & -0.791 & -0.833 & -1.121 \\
\hline & $(0.464)$ & $(0.466)$ & $(0.478)$ & $(0.501)$ & $(0.534)$ & $(0.752)$ \\
\hline \multirow[t]{2}{*}{ d_Asia } & $-1.291^{*}$ & $-1.286^{*}$ & $-1.346^{*}$ & $-1.484^{* *}$ & $-1.584^{* *}$ & $-1.619^{* *}$ \\
\hline & $(0.783)$ & $(0.768)$ & $(0.752)$ & $(0.666)$ & $(0.635)$ & $(0.651)$ \\
\hline \multirow[t]{2}{*}{ d_Western_Europe } & - & - & - & - & - & - \\
\hline & $(-)$ & $(-)$ & $(-)$ & $(-)$ & $(-)$ & $(-)$ \\
\hline \multirow[t]{2}{*}{ m2_reserves } & & & & 0.00641 & 0.00550 & 0.00196 \\
\hline & & & & $(0.0197)$ & $(0.0216)$ & $(0.0249)$ \\
\hline \multirow[t]{2}{*}{ credit_gdp } & & & & $0.0109^{* *}$ & $0.0122^{* *}$ & $0.00958^{*}$ \\
\hline & & & & $(0.00516)$ & $(0.00560)$ & $(0.00539)$ \\
\hline \multirow[t]{2}{*}{ L2.credit_growth } & & & & $0.0441^{*}$ & $0.0455^{*}$ & 4.541 \\
\hline & & & & $(0.0263)$ & $(0.0274)$ & $(4.449)$ \\
\hline \multirow[t]{2}{*}{ L.gini_market } & $0.0749^{*}$ & & & $0.161^{* *}$ & & \\
\hline & $(0.0427)$ & & & $(0.0812)$ & & \\
\hline \multirow[t]{2}{*}{ L2.gini_market } & & $0.0765^{*}$ & & & $0.172^{* *}$ & \\
\hline & & $(0.0438)$ & & & $(0.0801)$ & \\
\hline \multirow[t]{2}{*}{ L3.gini_market } & & & 0.0661 & & & $0.174^{* *}$ \\
\hline & & & $(0.0441)$ & & & $(0.0758)$ \\
\hline Observations & 588 & 575 & 566 & 403 & 399 & 392 \\
\hline No. crises & 24 & 24 & 24 & 20 & 20 & 20 \\
\hline$\%$ Total Correct & 96.09 & 96 & 96.11 & 96.03 & 95.99 & 95.92 \\
\hline$\%$ Crises Correct & 4.167 & 8.333 & 8.333 & 20 & 20 & 20 \\
\hline$\%$ No-Crises Correct & 100 & 99.82 & 100 & 100 & 100 & 100 \\
\hline Pseudo R-sq & 0.200 & 0.199 & 0.198 & 0.307 & 0.310 & 0.318 \\
\hline Chi-sq & 40.16 & 39.77 & 39.41 & 48.81 & 49.28 & 50.21 \\
\hline $\mathrm{p}$-value & 0.00013 & 0.00015 & 0.00017 & 0.00004 & 0.00003 & 0.00002 \\
\hline $\mathrm{AIC}$ & 186.4 & 185.7 & 185.3 & 140.3 & 139.4 & 137.8 \\
\hline
\end{tabular}

Robust standard errors in parentheses.

*** $\mathrm{p}<0.01,{ }^{* *} \mathrm{p}<0.05,{ }^{*} \mathrm{p}<0.1$ 
Table 6: Results for the top 1\% income share including regional dummies

\begin{tabular}{|c|c|c|c|c|c|c|}
\hline Variables & $\begin{array}{c}(1) \\
\text { crisis }\end{array}$ & $\begin{array}{c}(2) \\
\text { crisis }\end{array}$ & $\begin{array}{c}(3) \\
\text { crisis }\end{array}$ & $\begin{array}{c}(4) \\
\text { crisis }\end{array}$ & $\begin{array}{c}(5) \\
\text { crisis }\end{array}$ & $\begin{array}{c}(6) \\
\text { crisis }\end{array}$ \\
\hline gdp_growth & $\begin{array}{c}-0.338^{* * *} \\
(0.130)\end{array}$ & $\begin{array}{c}-0.305^{* *} \\
(0.133)\end{array}$ & $\begin{array}{c}-0.324^{* * *} \\
(0.125)\end{array}$ & $\begin{array}{c}-0.308^{* *} \\
(0.120)\end{array}$ & $\begin{array}{c}-0.258^{* *} \\
(0.130)\end{array}$ & $\begin{array}{c}-0.293^{* *} \\
(0.118)\end{array}$ \\
\hline totchange & $\begin{array}{c}0.101^{* * *} \\
(0.0201)\end{array}$ & $\begin{array}{c}0.111^{* * *} \\
(0.0181)\end{array}$ & $\begin{array}{c}0.0897^{* * *} \\
(0.0325)\end{array}$ & $\begin{array}{c}0.0923^{* * *} \\
(0.0205)\end{array}$ & $\begin{array}{c}0.112^{* * *} \\
(0.0239)\end{array}$ & $\begin{array}{c}0.0940^{* * *} \\
(0.0337)\end{array}$ \\
\hline depreciation & $\begin{array}{c}-0.0579^{* * *} \\
(0.0168)\end{array}$ & $\begin{array}{c}-0.0653^{* * *} \\
(0.0145)\end{array}$ & $\begin{array}{c}-0.0534^{* * *} \\
(0.0170)\end{array}$ & $\begin{array}{c}-0.0698^{* * *} \\
(0.0239)\end{array}$ & $\begin{array}{c}-0.0805^{* * *} \\
(0.0249)\end{array}$ & $\begin{array}{c}-0.0734^{* *} \\
(0.0302)\end{array}$ \\
\hline realinterest & $\begin{array}{c}0.129 * \\
(0.0671)\end{array}$ & $\begin{array}{c}0.125 \\
(0.0832)\end{array}$ & $\begin{array}{c}0.0865 \\
(0.0720)\end{array}$ & $\begin{array}{c}0.187^{* *} \\
(0.0924)\end{array}$ & $\begin{array}{l}0.229 * \\
(0.135)\end{array}$ & $\begin{array}{c}0.166 \\
(0.141)\end{array}$ \\
\hline inflation & $\begin{array}{l}-0.0349 \\
(0.0790)\end{array}$ & $\begin{array}{l}-0.0216 \\
(0.0891)\end{array}$ & $\begin{array}{l}-0.0932 \\
(0.0827)\end{array}$ & $\begin{array}{l}0.00697 \\
(0.0926)\end{array}$ & $\begin{array}{l}0.0558 \\
(0.134)\end{array}$ & $\begin{array}{c}0.00295 \\
(0.127)\end{array}$ \\
\hline gdp_pc & $\begin{array}{c}0.0254^{*} \\
(0.0149)\end{array}$ & $\begin{array}{l}0.0250^{*} \\
(0.0148)\end{array}$ & $\begin{array}{c}0.0123 \\
(0.0121)\end{array}$ & $\begin{array}{c}0.0343^{* *} \\
(0.0165)\end{array}$ & $\begin{array}{c}0.0393^{* *} \\
(0.0176)\end{array}$ & $\begin{array}{l}0.0252^{*} \\
(0.0136)\end{array}$ \\
\hline d_NA_Australasia & $\begin{array}{c}-2.227^{* * *} \\
(0.821)\end{array}$ & $\begin{array}{c}-2.363^{* * *} \\
(0.777)\end{array}$ & $\begin{array}{c}-1.960^{* *} \\
(0.831)\end{array}$ & $\begin{array}{c}-1.838^{* *} \\
(0.881)\end{array}$ & $\begin{array}{c}-2.209^{* * *} \\
(0.819)\end{array}$ & $\begin{array}{c}-1.978^{* *} \\
(0.944)\end{array}$ \\
\hline d_South_Europe & $\begin{array}{c}0.261 \\
(0.489)\end{array}$ & $\begin{array}{l}0.0578 \\
(0.514)\end{array}$ & $\begin{array}{l}0.0643 \\
(0.342)\end{array}$ & $\begin{array}{c}0.472 \\
(0.499)\end{array}$ & $\begin{array}{c}0.369 \\
(0.565)\end{array}$ & $\begin{array}{c}0.210 \\
(0.403)\end{array}$ \\
\hline d_East_Europe & $\begin{array}{l}- \\
(-)\end{array}$ & $\begin{array}{l}- \\
(-)\end{array}$ & $\begin{array}{l}- \\
(-)\end{array}$ & $\begin{array}{l}- \\
(-)\end{array}$ & $\begin{array}{l}- \\
(-)\end{array}$ & $\begin{array}{l}- \\
(-)\end{array}$ \\
\hline d_Nordic & $\begin{array}{l}-0.154 \\
(0.439)\end{array}$ & $\begin{array}{l}-0.265 \\
(0.462)\end{array}$ & $\begin{array}{l}-0.414 \\
(0.346)\end{array}$ & $\begin{array}{l}0.0515 \\
(0.505)\end{array}$ & $\begin{array}{l}0.0634 \\
(0.601)\end{array}$ & $\begin{array}{l}-0.111 \\
(0.500)\end{array}$ \\
\hline d_Asia & $\begin{array}{c}-2.165^{* * *} \\
(0.750)\end{array}$ & $\begin{array}{c}-2.345^{* * *} \\
(0.695)\end{array}$ & $\begin{array}{c}-2.525^{* * *} \\
(0.628)\end{array}$ & $\begin{array}{c}-1.739^{* *} \\
(0.746)\end{array}$ & $\begin{array}{c}-1.872^{* *} \\
(0.748)\end{array}$ & $\begin{array}{c}-2.071^{* * *} \\
(0.608)\end{array}$ \\
\hline d_Western_Europe & $(-)$ & $(-)$ & $(-)$ & $(-)$ & $(-)$ & $(-)$ \\
\hline m2_reserves & & & & $\begin{array}{l}0.00597 \\
(0.0113)\end{array}$ & $\begin{array}{c}-0.00863 \\
(0.0408)\end{array}$ & $\begin{array}{l}0.00605 \\
(0.0117)\end{array}$ \\
\hline credit_gdp & & & & $\begin{array}{c}0.00794 \\
(0.00655)\end{array}$ & $\begin{array}{c}0.00823 \\
(0.00881)\end{array}$ & $\begin{array}{c}0.00533 \\
(0.00689)\end{array}$ \\
\hline L2.credit_growth & & & & $\begin{array}{c}-0.00210 \\
(0.0268)\end{array}$ & $\begin{array}{c}-0.00311 \\
(0.0319)\end{array}$ & $\begin{array}{c}2.118 \\
(4.394)\end{array}$ \\
\hline L.topincomep99 & $\begin{array}{c}26.53^{* * *} \\
(7.930)\end{array}$ & & & $\begin{array}{c}28.68^{* * *} \\
(9.440)\end{array}$ & & \\
\hline L2.topincomep99 & & $\begin{array}{c}26.94^{* * *} \\
(7.949)\end{array}$ & & & $\begin{array}{c}33.42^{* * *} \\
(11.19)\end{array}$ & \\
\hline L3.topincomep99 & & & $\begin{array}{c}15.07^{* * *} \\
(5.719) \\
\end{array}$ & & & $\begin{array}{c}23.42^{* * *} \\
(8.825) \\
\end{array}$ \\
\hline Observations & 408 & 402 & 392 & 324 & 321 & 317 \\
\hline No. crises & 15 & 15 & 15 & 14 & 14 & 14 \\
\hline$\%$ Total Correct & 96.81 & 96.77 & 96.43 & 96.30 & 96.26 & 95.90 \\
\hline$\%$ Crises Correct & 13.33 & 13.33 & 6.667 & 14.29 & 14.29 & 7.143 \\
\hline$\%$ No-Crises Correct & 100 & 100 & 100 & 100 & 100 & 100 \\
\hline Pseudo R-sq & 0.255 & 0.267 & 0.208 & 0.267 & 0.290 & 0.227 \\
\hline Chi-sq & 32.84 & 34.14 & 26.46 & 30.77 & 33.34 & 26.08 \\
\hline $\mathrm{p}$-value & 0.00180 & 0.00114 & 0.0147 & 0.0144 & 0.00665 & 0.0529 \\
\hline $\mathrm{AIC}$ & 119.7 & 117.9 & 124.9 & 114.6 & 111.7 & 118.6 \\
\hline
\end{tabular}

Robust standard errors in parentheses.

*** $\mathrm{p}<0.01, * * \mathrm{p}<0.05,{ }^{*} \mathrm{p}<0.1$ 
banks only account for $30 \%$ of total credit, while bank credit in countries like Germany or Greece can be around $90 \%$ of total credit (Denbiermont, Drehmann and Muksakunratana, 2013). Table A3 shows that the median level of total credit as a percentage of GDP is $117 \%$ compared to $69 \%$ for domestic bank credit. Consequently, the specifications are re-estimated including a measure for total credit which may also include cross-border credit and domestic credit from other financial institutions.

Table A9 in the Appendix shows the results for the Gini index and the top 1\% income shares including the broader measure of total credit. Both the Gini index and the top 1\% income share (columns 1 and 4) are highly statistically significant. Moreover, the coefficient estimate for the level of total credit (as a percentage of GDP) is positive and significant, while that of the growth rate of total credit is statistically insignificant.

Furthermore, Perugini, Hölscher and Collie (2016) consider aggregate measures of credit that include both household credit (the relevant type of credit according to the literature) and credit to firms. Moreover, the average correlation between the real growth rate in firm and household credit is only $40 \%$ across countries (Denbiermont, Drehmann and Muksakunratana, 2013). Columns 2-3 and 5-6 in Table A9 show the results for estimations including household and firm credit separately. The Gini index and the top $1 \%$ income share are both positive and highly statistically significant when including household or firm credit. Interestingly, both the level of household credit to GDP and the lagged growth rate of household credit are highly significant in the specifications that include the Gini index (column 2). However, both the level and growth rate of firm credit are not significant in any specification (columns 3 and 6). This result is consistent with the findings by Büyükkarabacak and Valev (2010). Consequently, household credit seems to be more important for financial stability compared to firm credit.

For the results presented in the previous Section all control variables except credit growth are contemporaneous, which may lead to endogeneity issues. To check if the coefficients are influenced by endogeneity we lag all control variables one period. Table A10 shows that the coefficients for the Gini index are highly significant when all control variables are lagged one period in the baseline specification. In addition, Table A11 shows that the significance of the top $1 \%$ income share is robust to lagging the control variables one period.

Among the lagged control variables, the coefficients of GDP per capita and the change in terms of trade typically remain positive and significant. The level of credit to GDP is highly significant and positive in all estimations with the Gini index. This finding reinforces the importance of the level of credit to GDP as a determinant of banking crises.

Interestingly, the coefficient of the growth rate of GDP switches to a positive sign and is highly significant as shown in Table A10. Consequently, the negative estimated coefficient of contemporaneous GDP growth shown in Tables 5 and 6 may be a consequence of the onset of the banking crisis rather than a cause of the 
crisis. Furthermore, the coefficient of nominal depreciation is not significant when lagged one period, which once again may be a consequence of endogeneity. In addition, the real interest rate becomes significant and positive when lagged one period, contrary to previous results.

Logit estimations with robust standard errors that are not clustered by country are shown in Table A12. The coefficient estimates for the Gini index in the baseline and extended model remain significant. Moreover, Table A13 shows that the coefficients for the Gini index are also positive and significant for probit regressions. In addition, the sign and significance of the critical coefficients seem quite stable with respect to the omission/inclusion of the additional regressors.

It is important to control for the quality of institutions and market regulations across countries. Estimations including regulation indices from the Fraser Institute in the Economic Freedom of the World database can be found in the Appendix (see Tables A14-A16). All regulation indexes take values between 0 and 10 , and a higher number implies more deregulation. The credit regulation index (code $5 \mathrm{~A}$ ) is a summary measure of (i) ownership of banks (ii) foreign bank competition (iii) private sector credit and (iv) interest rates controls/negative interest rates.

Furthermore, it is important to account for the institutional setting of labor and product markets. Labor market regulation (code 5B) includes information about (i) hiring regulations for temporary workers and minimum wage, (ii) hiring and firing regulations, (iii) centralized collective bargaining, (iv) hours regulation and (v) conscription and mandated costs of dismissal. In addition, the business regulation index encompasses information on (i) price controls, (ii) administrative requirements, (iii) bureaucracy costs, (iv) time and money required to start a business, (v) extra payments or bribes, (vi) licensing costs and (vii) cost of tax compliance. These measures have been used previously in the empirical literature for example by Perugini, Hölscher and Collie (2016) and Giannone, Lenza, and Reichlin (2011).

Table A14 reports results from Logit estimations including each regulation index separately and all together. First, we can see that the coefficients for both the Gini index and the top $1 \%$ income share are positive and significant in all estimations. Second, the business regulation index (business_reg) is negative and highly significant, while the credit regulation index (credit_reg) and the labor regulation index (labour_reg) are not. These findings suggest that a more deregulated product market seems to lower the probability of banking crises. To conclude, the previous finding that the Gini index and top 1\% income share are positively associated with the likelihood of banking crises seems robust with respect to the inclusion of regulation indices for credit, labor and product markets.

According to Piketty and Saez (2013), a booming stock market both increases top income shares (via higher capital gains) and enhances financial fragility. Stock market conditions are proxied by a share price index collected from the OECD database. If the contemporaneous level of the share price index is included, 
its coefficient is insignificant. Moreover, the contemporaneous coefficient for the growth rate of the share price index is negative and significant at the $1 \%$ level. This result is expected since banking crises often coincide with a collapse in stock prices.

Tables A15 and A16 show results for the top 1\% income share when the level and growth rate of the share price index are lagged one period. The lagged coefficients for both the level and growth rate of the share price index and the top $1 \%$ income share are positive and typically significant. In short, results suggest that the positive association between the top $1 \%$ income share and the likelihood of banking crises previously found is not simply a correlation caused by a booming stock market.

\section{Conclusions}

This paper is one of the first to empirically investigate whether the level of income inequality is directly linked to the occurrence of banking crises. Previous empirical literature examining the "level" hypothesis either used descriptive statistics (for example Atkinson and Morelli, 2015), or investigated the indirect link between income inequality and banking crises via the level of credit in the economy (Perugini, Hölscher and Collie, 2016).

We conduct an econometric analysis based on logit regressions to estimate the relationship between the level of the Gini index or top $1 \%$ income shares (both before taxes and transfers) and banking crises. Using a panel dataset of 33 advanced countries over the period 1970-2011, we find strong evidence for a positive association between the probability of banking crises and the level of income inequality. In addition, the results successfully pass a battery of robustness tests, such as for example the inclusion of the level and growth rate of domestic bank credit and the exclusion of various groups of countries.

Furthermore, we find that the effect of an increase in the level of inequality on the probability of the occurrence of a banking crisis is relatively large in economic terms, and that the size of the effect seems to increase with the level of income inequality.

Although income inequality could influence the probability of a banking crisis through several channels, to set up a fully-fledged theoretical model supporting our empirical findings goes beyond the scope of this paper. ${ }^{8}$

A possible mechanism, consistent with our empirical findings, that links income inequality and banking crises is the following. Persistently high levels of (before-tax) income inequality may induce policy makers to increase redistribution through large public expenditure and taxation mechanisms like those pioneered by Meltzer and Richard (1981), and later extended to growth by Alesina and Rodrik (1994) and Persson and

\footnotetext{
${ }^{8}$ With the exception of Kumhof, Ranciere and Winant (2015), we are not aware of theoretical contributions displaying a neat relationship between income inequality and financial crises. Kirschenmann, Malinen and Nyberg (2016) discuss the literature and describe some of these channels.
} 
Tabellini (1994). Worsening public deficits and debts (and rising interest rates), such policies may depress growth and ultimately deteriorate banks stability.

To conclude, it is worth mentioning that almost all biggest economies of our samples display a positive association between persistently high levels of income inequality and the occurrence of banking crises. Insofar as high levels of income inequality are associated to banking crises in large economies, inequality should be taken very seriously at the international level as financial integration might easily give rise to epidemic contagion worldwide.

\section{Acknowledgement}

We thank conference audiences in Rome and Palermo (Money, Banking and Finance, December 2017), Milan (Finance and Economic Growth in the Aftermath of the Crisis, September 2017) and Bologna (Trends in Inequality: Social, Economic and Political Issues, November 2017). We also thank Gabriella Chiesa, Henriette Prast, and Paolo Manasse for helpful comments on earlier drafts. The usual disclaimer applies. 


\section{References}

Alesina A., Rodrik D., 1994, "Distributive Politics and Economic Growth", Quarterly Journal of Economics, $109,465-89$.

Atkinson, A. and S. Morelli (2011), "Economic Crises and Inequality", UNDP, Research Paper 2011/6.

Atkinson, A. and S. Morelli (2014), "Chartbook of Economic Inequality", ECINEQ working paper n. 324.

Atkinson, A. and S. Morelli (2015), "Inequality and Crises Revisited", Economia Politica, 31, 31-51.

Bazillier, R. and J. Hericourt (2017), "The Circular Relationship between Inequality, Leverage, and Financial Crises", Journal of Economic Surveys, 31, 463-96.

Bellettini, G. and F. Delbono (2013), "Persistence of High Income Inequality and Banking Crises: 19802010", CESifo working paper n. 4293.

Bordo, M. and C. Meissner (2012), "Does Inequality Lead to a Financial Crisis?", Journal of International Money and Finance, 31, 2147-61.

Büyükkarabacak, B. and N. T. Valev (2010), "The role of business and household credit in banking crises", Journal of Banking and Finance, 34(6), 1247-1256.

Dembiermont C., Drehmann M. and S. Muksakunratana (2013), "How much does the private sector really borrow a new database for total credit to the private non-financial sector", BIS Quarterly Review.

Demirg-Kunt, A. and E. Detragiache (2005), "Cross-country empirical studies of systemic bank distress: a survey", National Institute Economic Review, 192, 68-83

Duttagupta, R. and P. Cashin (2011), "Anatomy of banking crises in developing and emerging countries", Journal of International Money and Finance, 30, 354-376

Fitoussi, J.-P. and F. Saraceno (2009), "How Deep is a Crisis? Policy Responses and Structural Factors behind Diverging Performances", OFCE/POLHIA 2009-31.

Galbraith, J. K., 1954, The Great Crash, 1929, London, Penguin.

Giannone, D., Lenza, M. and L. Reichlin (2011), "Market Freedom and the Global Recession", IMF Economic Review, 59, 111-135.

Gu, X. and B. Huang (2014), "Does Inequality Lead to a Financial Crisis. Revisited", Review of Development Economics, 18. 502-16. 
Hutchison, M. M. (2002), "European Banking Distress and EMU: Institutional and Macroeconomic Risks", Scandinavian Journal of Economics, 104, 365-389.

Iacoviello, M. (2008), "Household Debt and Income Inequality, 1963-2003", Journal of Money, Credit and Banking, 40, 929-965.

Kirschenmann, K., T. Malinen and H. Nyberg (2016), "The Risk of Financial Crises: Is there a Role for Income Inequality?", Journal of International Money and Finance, 68, 161-80.

Klein, M. (2015), "Inequality and Household Debt: a Panel Cointegration Analysis", Empirica, 42, $391-412$.

Kumhof, M., R. Ranciere and P. Winant (2015), "Inequality, Leverage and Crises", American Economic Review, 105, 1217-45.

Krugman P., 2007, The Conscience of a Liberal, New York, Norton.

Laeven, L. and F. Valencia (2013), "Systemic Banking Crises Database", IMF Economic Review, 61, 225-270.

Magud, N.E. and E.R. Vesperoni (2015), "Exchange rate flexibility and credit during capital inflow reversals: Purgatory not paradise", Journal of International Money and Finance, 55, 88-110.

Malinen, T. (2016), "Does income inequality contribute to credit cycles?", Journal of Economic Inequality, $14,309-325$.

Meltzer A.H., Richard S.F. (1981), "A Rational Theory of the Size of the Government", Journal of Political Economy, 89, 914-927.

Persson T., Tabellini G. (1994), "Is Inequality Harmful to Growth? Theory and Evidence", American Economic Review, 84, 600-21.

Perugini, C., J. Hölscher and S. Collie (2016), "Inequality, Credit and Financial Crises", Cambridge Journal of Economics, 40, 227-57.

Piketty, T., (2007), "Top incomes over the twentieth century: a summary of main findings", in: Atkinson, A.B., Piketty, T. (Eds.), Top Income Over the Twentieth Century: A Contrast between European and English-Speaking Countries, Oxford University Press, Oxford.

Piketty T. and E. Saez (2013), "Top Incomes and the Great Recession: Recent Evolution and Policy Implications", IMF Economic Review, 61, 456-478.

Rajan, R. (2010), Fault Lines, Princeton, Princeton University Press. 
Roy, S. and D. Kemme (2012), "Causes of Banking Crises: Deregulation, Credit Booms and Asset Bubbles", International Review of Economics and Finance, 24, 270-94.

Schularik, M. and A.M. Taylor (2012), "Credit Booms Gone Bust: Monetary Policy, Leverage Cycles and Financial Crises", American Economic Review, 102, 1029-61.

Solt, F., (2016), "The Standardized World Income Database", Social Science Quarterly, 90, 231-242.

Stiglitz, J. (2012), The Price of Inequality, New York, Norton.

UNU-WIDER (2008), "World Income Inequality Database (WIID)", Version 2.0.c, May.

Van Treeck, T. (2014), "Did Inequality Cause the U.S. Financial Crisis?", Journal of Economic Surveys, 28, 421-48. 
Appendix 
Table A1: Definitions and sources of main variables

\begin{tabular}{|c|c|c|}
\hline Variable & Definition & Source \\
\hline crisis & $\begin{array}{l}\text { A binary variable equal to } 1 \\
\text { in the first year of a banking } \\
\text { crisis, } 0 \text { otherwise. }\end{array}$ & Laeven and Valencia (2013). \\
\hline gini_gross & $\begin{array}{l}\text { Market Gini index pre-tax } \\
\text { and pre-transfer. }\end{array}$ & $\begin{array}{l}\text { Standard World Income Inequality Database } \\
\text { (SWIID) version 5.1. }\end{array}$ \\
\hline topincomep99 & $\begin{array}{l}\text { The income share of top } 1 \% \\
\text { pre-tax and pre-transfer }\end{array}$ & World Top Incomes Database. \\
\hline gdp_growth & Growth rate of real GDP. & World Bank WDI. \\
\hline totchange & Change in terms of trade. & World Bank WDI. \\
\hline realinterest & $\begin{array}{l}\text { Nominal interest rate minus } \\
\text { contemporaneous inflation. }\end{array}$ & $\begin{array}{l}\text { The nominal interest rate is from IFS: (i) trea- } \\
\text { sure bill rate or (ii) discount/bank rate or (iii) } \\
\text { the deposit rate. The GDP deflator based In- } \\
\text { flation is from World Bank WDI. }\end{array}$ \\
\hline inflation & $\begin{array}{l}\text { Rate of change of GDP defla- } \\
\text { tor. }\end{array}$ & World Bank WDI. \\
\hline m2_reserves & $\begin{array}{l}\text { Ratio of M2 to international } \\
\text { reserves. }\end{array}$ & $\begin{array}{l}\text { M2 (money plus quasi-money in local cur- } \\
\text { rency) that is converted to US } \$ \text { and divided } \\
\text { by total foreign exchange reserves of the cen- } \\
\text { tral bank. All data is from IMF IFS. }\end{array}$ \\
\hline depreciation & Rate of depreciation. & USD/LCU exchange rate (IMF IFS). \\
\hline gdp1_pc & Real GDP per capita. & $\begin{array}{l}\text { Constant } 1995 \text { in thousands of US } \$ \text { (World } \\
\text { Bank WDI). }\end{array}$ \\
\hline credit_gdp & $\begin{array}{l}\text { Ratio of private sector bank } \\
\text { credit to GDP. }\end{array}$ & $\begin{array}{l}\text { Adjusted domestic bank credit to the private } \\
\text { non-financial sector divided by GDP (BIS to- } \\
\text { tal credit statistics). Otherwise depository } \\
\text { corporations domestic claims on private sector } \\
\text { (IMF IFS) divided by nominal GDP (World } \\
\text { Bank WDI). All in LCU. }\end{array}$ \\
\hline credit_growth & $\begin{array}{l}\text { Growth rate of real domestic } \\
\text { bank credit to the private sec- } \\
\text { tor. }\end{array}$ & $\begin{array}{l}\text { Adjusted domestic bank credit to the private } \\
\text { non-financial sector (BIS total credit statis- } \\
\text { tics), otherwise depository corporations do- } \\
\text { mestic claims on private sector (IMF IFS); } \\
\text { divided by the GDP deflator (World Bank } \\
\text { WDI). All in LCU. }\end{array}$ \\
\hline
\end{tabular}


Table A2: Definitions and sources of additional variables used in robustness tests

\begin{tabular}{|c|c|c|}
\hline Variable & Definition & Source \\
\hline totalcredit_gdp & $\begin{array}{l}\text { Ratio of private sector total credit to } \\
\text { GDP. This variable includes domes- } \\
\text { tic bank credit, cross-border credit } \\
\text { and domestic credit from other fi- } \\
\text { nancial institutions. }\end{array}$ & $\begin{array}{l}\text { Adjusted total credit to the private non-financial } \\
\text { sector divided by GDP (BIS total credit statis- } \\
\text { tics). }\end{array}$ \\
\hline totalcredit_growth & $\begin{array}{l}\text { Growth rate of real total credit to } \\
\text { the private sector. This variable in- } \\
\text { cludes domestic bank credit, cross- } \\
\text { border credit and domestic credit } \\
\text { from other financial institutions. }\end{array}$ & $\begin{array}{l}\text { Adjusted total credit to the private non-financial } \\
\text { sector (BIS total credit statistics); divided by the } \\
\text { GDP deflator (World Bank WDI). All in LCU. }\end{array}$ \\
\hline hhcredit_gdp & $\begin{array}{l}\text { Ratio of private sector household } \\
\text { credit to GDP. }\end{array}$ & $\begin{array}{l}\text { Adjusted household credit to the private non- } \\
\text { financial sector divided by GDP (BIS total credit } \\
\text { statistics). }\end{array}$ \\
\hline hhcredit_growth & $\begin{array}{l}\text { Growth rate of real household credit } \\
\text { to the private sector. }\end{array}$ & $\begin{array}{l}\text { Adjusted household credit to the private non- } \\
\text { financial sector (BIS total credit statistics); di- } \\
\text { vided by the GDP deflator (World Bank WDI). } \\
\text { All in LCU. }\end{array}$ \\
\hline firmcredit_gdp & $\begin{array}{l}\text { Ratio of private sector firm credit to } \\
\text { GDP. }\end{array}$ & $\begin{array}{l}\text { Adjusted firm credit to the private non-financial } \\
\text { sector divided by GDP (BIS total credit statis- } \\
\text { tics). }\end{array}$ \\
\hline firmcredit_growth & $\begin{array}{l}\text { Growth rate of real firm credit to the } \\
\text { private sector. }\end{array}$ & $\begin{array}{l}\text { Adjusted firm credit to the private non-financial } \\
\text { sector (BIS total credit statistics); divided by the } \\
\text { GDP deflator (World Bank WDI). All in LCU. }\end{array}$ \\
\hline credit_reg & $\begin{array}{l}\text { Credit regulation index taking val- } \\
\text { ues from } 0 \text { to } 10 \text {. A higher number } \\
\text { implies more deregulation. }\end{array}$ & $\begin{array}{l}\text { Economic Freedom of the World database (Fraser } \\
\text { institute). }\end{array}$ \\
\hline labor_reg & $\begin{array}{l}\text { Labor market regulation index tak- } \\
\text { ing values from } 0 \text { to } 10 \text {. A higher } \\
\text { number implies more deregulation. }\end{array}$ & $\begin{array}{l}\text { Economic Freedom of the World database (Fraser } \\
\text { institute). }\end{array}$ \\
\hline business_reg & $\begin{array}{l}\text { Business regulation index taking } \\
\text { values from } 0 \text { to } 10 \text {. A higher num- } \\
\text { ber implies more deregulation. }\end{array}$ & $\begin{array}{l}\text { Economic Freedom of the World database (Fraser } \\
\text { institute). }\end{array}$ \\
\hline house_index & Real house price index & OECD \\
\hline share_index & Share price index & OECD \\
\hline topincomep999 & $\begin{array}{l}\text { The income share of top } 0.1 \% \text { pre- } \\
\text { tax and pre-transfer. }\end{array}$ & World Top Incomes Database. \\
\hline topincomep95 & $\begin{array}{l}\text { The income share of top } 5 \% \text { pre-tax } \\
\text { and pre-transfer. }\end{array}$ & World Top Incomes Database. \\
\hline topincomep90 & $\begin{array}{l}\text { The income share of top } 10 \% \text { pre-tax } \\
\text { and pre-transfer. }\end{array}$ & World Top Incomes Database. \\
\hline
\end{tabular}


Table A3: Descriptive statistics

\begin{tabular}{lllllll}
\hline \hline Variable & Mean & Median & Std. Dev. & Min & Max & Obs. \\
\hline Bank crisis & 0.09 & 0 & 0.15 & 0 & 1 & 1386 \\
Market Gini index & 43.41 & 44.20 & 6.08 & 24.47 & 58.59 & 1040 \\
Top 0.1\% income share & 0.03 & 0.02 & 0.02 & 0.01 & 0.12 & 595 \\
Top 1\% income share & 0.09 & 0.08 & 0.03 & 0.04 & 0.23 & 662 \\
Top 5\% income share & 0.21 & 0.21 & 0.04 & 0.12 & 0.37 & 665 \\
Top 10\% income share & 0.32 & 0.31 & 0.05 & 0.19 & 0.47 & 659 \\
GDP growth & 3.35 & 3.21 & 3.41 & -14.81 & 16.16 & 1217 \\
Change in terms of trade & $1.20 \times 10^{12}$ & 0 & $6.82 \times 10^{12}$ & $-3.26 \times 10^{13}$ & $6.97 \times 10^{13}$ & 1201 \\
Depreciation & 7.88 & -0.06 & 257.10 & -99.29 & 7533.67 & 861 \\
Real interest rate & 1.25 & 1.35 & 3.97 & -19.43 & 20.11 & 745 \\
Inflation & 7.24 & 4.02 & 16.87 & -9.69 & 390.68 & 1217 \\
GDP per capita & 31381.71 & 29192 & 16752.88 & 1960.36 & 110001.1 & 1227 \\
Ratio M2 to Inter. Res. & 123602.6 & 66.84 & 2130872 & 0.90 & $4.22 \times 10^{7}$ & 623 \\
Credit to GDP & 76.58 & 68.58 & 34.37 & 20.7 & 312.12 & 1071 \\
Credit growth & 0.06 & 0.05 & 0.07 & -0.21 & 0.60 & 1032 \\
Total credit to GDP & 123.21 & 117.43 & 49.51 & 29.3 & 421.43 & 1043 \\
Total credit growth & 0.06 & 0.05 & 0.06 & -0.13 & 0.78 & 999 \\
Household credit to GDP & 50.12 & 46.89 & 24.52 & 5.93 & 137.95 & 774 \\
Household credit growth & 0.07 & 0.06 & 0.07 & -0.20 & 0.61 & 747 \\
Firm credit to GDP & 83.73 & 79.58 & 36.17 & 26.13 & 369.23 & 752 \\
Firm credit growth & 0.05 & 0.04 & 0.07 & -0.15 & 0.92 & 730 \\
Credit regulation index & 8.72 & 9.26 & 1.50 & 0 & 10 & 566 \\
Labour regulation index & 5.97 & 5.7 & 1.70 & 2.62 & 9.46 & 529 \\
Business regulation index & 6.79 & 6.78 & 0.92 & 3.91 & 9.5 & 424 \\
Real house price index & 75.17 & 72.18 & 31.18 & 24.10 & 188.54 & 890 \\
Share price index & 66.19 & 47.82 & 78.37 & 0.01 & 1246.92 & 947 \\
\hline \hline
\end{tabular}


Table A4: Results for Gini index including regional and period dummies

\begin{tabular}{|c|c|c|c|c|c|c|}
\hline Variables & $\begin{array}{l}(1) \\
\text { crisis }\end{array}$ & $\begin{array}{l}(2) \\
\text { crisis }\end{array}$ & $\begin{array}{l}(3) \\
\text { crisis }\end{array}$ & $\begin{array}{c}(4) \\
\text { crisis }\end{array}$ & $\begin{array}{c}(5) \\
\text { crisis }\end{array}$ & $\begin{array}{c}(6) \\
\text { crisis }\end{array}$ \\
\hline gdp_growth & $\begin{array}{c}-0.191^{* * *} \\
(0.0664)\end{array}$ & $\begin{array}{c}-0.191^{* * *} \\
(0.0663)\end{array}$ & $\begin{array}{c}-0.191^{* * *} \\
(0.0663)\end{array}$ & $\begin{array}{c}-0.364^{* * *} \\
(0.0794)\end{array}$ & $\begin{array}{c}-0.378^{* * *} \\
(0.0800)\end{array}$ & $\begin{array}{c}-0.374^{* * *} \\
(0.0818)\end{array}$ \\
\hline totchange & $\begin{array}{c}0.0570^{* * *} \\
(0.0201)\end{array}$ & $\begin{array}{c}0.0565^{* * *} \\
(0.0203)\end{array}$ & $\begin{array}{c}0.0546^{* * *} \\
(0.0194)\end{array}$ & $\begin{array}{c}0.141^{* * *} \\
(0.0482)\end{array}$ & $\begin{array}{c}0.144^{* * *} \\
(0.0502)\end{array}$ & $\begin{array}{c}0.143^{* * *} \\
(0.0481)\end{array}$ \\
\hline depreciation & $\begin{array}{c}-0.0661^{* * *} \\
(0.0155)\end{array}$ & $\begin{array}{c}-0.0661^{* * *} \\
(0.0155)\end{array}$ & $\begin{array}{c}-0.0659^{* * *} \\
(0.0160)\end{array}$ & $\begin{array}{c}-0.0832^{\text {*** }} \\
(0.0229)\end{array}$ & $\begin{array}{c}-0.0818^{* * *} \\
(0.0227)\end{array}$ & $\begin{array}{c}-0.0822^{* * *} \\
(0.0246)\end{array}$ \\
\hline realinterest & $\begin{array}{c}0.0352 \\
(0.0965)\end{array}$ & $\begin{array}{c}0.0397 \\
(0.0949)\end{array}$ & $\begin{array}{c}0.0366 \\
(0.0989)\end{array}$ & $\begin{array}{l}0.0470 \\
(0.187)\end{array}$ & $\begin{array}{l}0.0566 \\
(0.182)\end{array}$ & $\begin{array}{l}0.0363 \\
(0.208)\end{array}$ \\
\hline inflation & $\begin{array}{c}0.101 \\
(0.0769)\end{array}$ & $\begin{array}{c}0.104 \\
(0.0749)\end{array}$ & $\begin{array}{c}0.103 \\
(0.0749)\end{array}$ & $\begin{array}{c}-0.0653 \\
(0.0939)\end{array}$ & $\begin{array}{c}-0.0553 \\
(0.0963)\end{array}$ & $\begin{array}{c}-0.0559 \\
(0.0978)\end{array}$ \\
\hline gdp_pc & $\begin{array}{c}0.0227^{* *} \\
(0.0105)\end{array}$ & $\begin{array}{c}0.0228^{* *} \\
(0.0103)\end{array}$ & $\begin{array}{c}0.0225^{* *} \\
(0.0102)\end{array}$ & $\begin{array}{c}0.0671^{* *} \\
(0.0300)\end{array}$ & $\begin{array}{c}0.0681^{* *} \\
(0.0300)\end{array}$ & $\begin{array}{c}0.0661^{* *} \\
(0.0289)\end{array}$ \\
\hline d_NA_Australasia & $\begin{array}{l}-1.012 \\
(1.073)\end{array}$ & $\begin{array}{l}-1.032 \\
(1.098)\end{array}$ & $\begin{array}{l}-1.055 \\
(1.097)\end{array}$ & $\begin{array}{l}-0.333 \\
(1.050)\end{array}$ & $\begin{array}{l}-0.319 \\
(1.069)\end{array}$ & $\begin{array}{l}-0.332 \\
(1.015)\end{array}$ \\
\hline d_South_Europe & $\begin{array}{c}0.106 \\
(0.501)\end{array}$ & $\begin{array}{c}0.104 \\
(0.514)\end{array}$ & $\begin{array}{c}0.109 \\
(0.506)\end{array}$ & $\begin{array}{c}0.885 \\
(0.577)\end{array}$ & $\begin{array}{c}0.902 \\
(0.570)\end{array}$ & $\begin{array}{c}0.814 \\
(0.555)\end{array}$ \\
\hline d_East_Europe & $\begin{array}{c}-0.00757 \\
(0.953)\end{array}$ & $\begin{array}{c}-0.0270 \\
(0.959)\end{array}$ & $\begin{array}{c}-0.0283 \\
(0.955)\end{array}$ & $\begin{array}{l}- \\
(-)\end{array}$ & $\begin{array}{l}- \\
(-)\end{array}$ & $\begin{array}{l}- \\
(-)\end{array}$ \\
\hline d_Nordic & $\begin{array}{l}-0.655 \\
(0.435)\end{array}$ & $\begin{array}{l}-0.644 \\
(0.450)\end{array}$ & $\begin{array}{l}-0.681 \\
(0.456)\end{array}$ & $\begin{array}{l}-0.847 \\
(0.743)\end{array}$ & $\begin{array}{l}-0.880 \\
(0.783)\end{array}$ & $\begin{array}{l}-0.850 \\
(0.763)\end{array}$ \\
\hline d_Asia & $\begin{array}{l}-1.363 \\
(0.857)\end{array}$ & $\begin{array}{l}-1.367 \\
(0.846)\end{array}$ & $\begin{array}{c}-1.402^{*} \\
(0.839)\end{array}$ & $\begin{array}{c}-1.685^{* *} \\
(0.751)\end{array}$ & $\begin{array}{c}-1.757^{* *} \\
(0.715)\end{array}$ & $\begin{array}{c}-1.926^{* * *} \\
(0.710)\end{array}$ \\
\hline d_Western_Europe & $\begin{array}{l}- \\
(-)\end{array}$ & $\begin{array}{l}- \\
(-)\end{array}$ & $\begin{array}{l}- \\
(-)\end{array}$ & $\begin{array}{l}- \\
(-)\end{array}$ & $\begin{array}{l}- \\
(-)\end{array}$ & $\begin{array}{l}- \\
(-)\end{array}$ \\
\hline d_1980s & $\begin{array}{c}13.24^{* * *} \\
(1.235)\end{array}$ & $\begin{array}{c}13.66^{* * *} \\
(1.183)\end{array}$ & $\begin{array}{c}13.81^{* * *} \\
(1.197)\end{array}$ & $\begin{array}{l}271.2 \\
(344.9)\end{array}$ & $\begin{array}{l}290.0 \\
(378.2)\end{array}$ & $\begin{array}{c}16.15^{* * *} \\
(2.275)\end{array}$ \\
\hline d_1990s & $\begin{array}{c}14.91^{* * *} \\
(1.153)\end{array}$ & $\begin{array}{c}15.34^{* * *} \\
(1.297)\end{array}$ & $\begin{array}{c}15.38^{* * *} \\
(1.252)\end{array}$ & $\begin{array}{l}269.6 \\
(344.0)\end{array}$ & $\begin{array}{l}288.7 \\
(377.3)\end{array}$ & $\begin{array}{c}14.39^{* * *} \\
(1.172)\end{array}$ \\
\hline $\mathrm{d}_{-} 2000 \mathrm{~s}$ & $\begin{array}{c}14.66^{* * *} \\
(1.127)\end{array}$ & $\begin{array}{c}15.07^{* * * *} \\
(1.253)\end{array}$ & $\begin{array}{c}15.09^{* * *} \\
(1.208)\end{array}$ & $\begin{array}{c}269.7 \\
(344.0)\end{array}$ & $\begin{array}{c}288.7 \\
(377.3)\end{array}$ & $\begin{array}{c}14.44^{* * *} \\
(0.829)\end{array}$ \\
\hline m2_reserves & & & & $\begin{array}{c}0.00170 \\
(0.0332)\end{array}$ & $\begin{array}{c}0.00100 \\
(0.0333)\end{array}$ & $\begin{array}{c}0.00279 \\
(0.0329)\end{array}$ \\
\hline credit_gdp & & & & $\begin{array}{c}0.0136^{* *} \\
(0.00675)\end{array}$ & $\begin{array}{c}0.0141^{* *} \\
(0.00640)\end{array}$ & $\begin{array}{c}0.0157^{* *} \\
(0.00702)\end{array}$ \\
\hline L2.credit_growth & & & & $\begin{array}{c}3.393 \\
(4.403)\end{array}$ & $\begin{array}{c}3.636 \\
(4.831)\end{array}$ & $\begin{array}{c}2.975 \\
(4.570)\end{array}$ \\
\hline L.gini_market & $\begin{array}{c}0.0514 \\
(0.0513)\end{array}$ & & & $\begin{array}{l}0.203^{*} \\
(0.108)\end{array}$ & & \\
\hline L2.gini_market & & $\begin{array}{c}0.0519 \\
(0.0523)\end{array}$ & & & $\begin{array}{l}0.211^{*} \\
(0.112)\end{array}$ & \\
\hline L3.gini_market & & & $\begin{array}{c}0.0459 \\
(0.0532)\end{array}$ & & & $\begin{array}{l}0.208^{*} \\
(0.107)\end{array}$ \\
\hline Observations & 588 & 575 & 566 & 403 & 399 & 392 \\
\hline No. crises & 24 & 24 & 24 & 20 & 20 & 20 \\
\hline$\%$ Total Correct & 96.26 & 96.17 & 96.11 & 95.78 & 95.99 & 95.92 \\
\hline \% Crises Correct & 8.333 & 8.333 & 8.333 & 20 & 20 & 20 \\
\hline$\%$ No-Crises Correct & 100 & 100 & 100 & 99.74 & 100 & 100 \\
\hline Pseudo R-sq & 0.230 & 0.229 & 0.227 & 0.331 & 0.333 & 0.335 \\
\hline Chi-sq & 46.17 & 45.67 & 45.13 & 52.69 & 52.83 & 52.89 \\
\hline $\mathrm{p}$-value & $9.16 \mathrm{e}-05$ & 0.000110 & 0.000133 & $5.22 \mathrm{e}-05$ & $4.97 \mathrm{e}-05$ & $4.87 \mathrm{e}-05$ \\
\hline $\mathrm{AIC}$ & 186.4 & 185.8 & 185.5 & 142.4 & 141.9 & 141.1 \\
\hline
\end{tabular}

Robust standard errors in parentheses.

*** $\mathrm{p}<0.01,{ }^{* *} \mathrm{p}<0.05,{ }^{*} \mathrm{p}<0.1$ 
Table A5: Results for top 1\% income share including regional and period dummies

\begin{tabular}{|c|c|c|c|c|c|c|}
\hline & (1) & $(2)$ & $(3)$ & $(4)$ & $(5)$ & $(6)$ \\
\hline Variables & crisis & crisis & crisis & crisis & crisis & crisis \\
\hline gdp_growth & $\begin{array}{c}-0.335^{* *} \\
(0.135)\end{array}$ & $\begin{array}{c}-0.306^{* *} \\
(0.146)\end{array}$ & $\begin{array}{c}-0.333^{* *} \\
(0.149)\end{array}$ & $\begin{array}{c}-0.304^{* * *} \\
(0.111)\end{array}$ & $\begin{array}{c}-0.253^{* *} \\
(0.119)\end{array}$ & $\begin{array}{c}-0.298^{* *} \\
(0.131)\end{array}$ \\
\hline totchange & $\begin{array}{c}0.0936^{* * * *} \\
(0.0222)\end{array}$ & $\begin{array}{c}0.104^{* * *} \\
(0.0193)\end{array}$ & $\begin{array}{c}0.0775^{* *} \\
(0.0340)\end{array}$ & $\begin{array}{c}0.0970 * * * \\
(0.0326)\end{array}$ & $\begin{array}{c}0.118^{* * *} \\
(0.0311)\end{array}$ & $\begin{array}{c}0.0827^{* *} \\
(0.0346)\end{array}$ \\
\hline depreciation & $\begin{array}{c}-0.0550^{* * *} \\
(0.0158)\end{array}$ & $\begin{array}{c}-0.0608^{* * *} \\
(0.0145)\end{array}$ & $\begin{array}{c}-0.0494^{* * *} \\
(0.0163)\end{array}$ & $\begin{array}{c}-0.0684^{* * *} \\
(0.0239)\end{array}$ & $\begin{array}{c}-0.0827^{* * *} \\
(0.0230)\end{array}$ & $\begin{array}{c}-0.0688^{* *} \\
(0.0273)\end{array}$ \\
\hline realinterest & $\begin{array}{c}0.126 \\
(0.0854)\end{array}$ & $\begin{array}{c}0.127 \\
(0.0967)\end{array}$ & $\begin{array}{c}0.109 \\
(0.0999)\end{array}$ & $\begin{array}{c}0.166 \\
(0.119)\end{array}$ & $\begin{array}{c}0.189 \\
(0.140)\end{array}$ & $\begin{array}{c}0.176 \\
(0.137)\end{array}$ \\
\hline inflation & $\begin{array}{c}-0.0130 \\
(0.140)\end{array}$ & $\begin{array}{l}0.0111 \\
(0.148)\end{array}$ & $\begin{array}{c}-0.0250 \\
(0.167)\end{array}$ & $\begin{array}{c}-0.0492 \\
(0.109)\end{array}$ & $\begin{array}{c}-0.0179 \\
(0.132)\end{array}$ & $\begin{array}{c}0.00851 \\
(0.143)\end{array}$ \\
\hline gdp_pc & $\begin{array}{c}0.0207 \\
(0.0177)\end{array}$ & $\begin{array}{c}0.0194 \\
(0.0184)\end{array}$ & $\begin{array}{l}0.00718 \\
(0.0145)\end{array}$ & $\begin{array}{c}0.0331^{*} \\
(0.0183)\end{array}$ & $\begin{array}{c}0.0379^{* *} \\
(0.0181)\end{array}$ & $\begin{array}{l}0.0251^{*} \\
(0.0134)\end{array}$ \\
\hline d_NA_Australasia & $\begin{array}{c}-2.056^{* * *} \\
(0.759)\end{array}$ & $\begin{array}{c}-2.244^{* * *} \\
(0.741)\end{array}$ & $\begin{array}{c}-1.856^{*} \\
(0.948)\end{array}$ & $\begin{array}{c}-1.763^{*} \\
(0.901)\end{array}$ & $\begin{array}{c}-2.203^{* * *} \\
(0.849)\end{array}$ & $\begin{array}{c}-1.652^{*} \\
(0.935)\end{array}$ \\
\hline d_South_Europe & $\begin{array}{c}0.271 \\
(0.566)\end{array}$ & $\begin{array}{r}0.0888 \\
(0.607)\end{array}$ & $\begin{array}{l}0.0461 \\
(0.410)\end{array}$ & $\begin{array}{c}0.500 \\
(0.600)\end{array}$ & $\begin{array}{c}0.407 \\
(0.660)\end{array}$ & $\begin{array}{c}0.421 \\
(0.413)\end{array}$ \\
\hline d_East_Europe & $\begin{array}{l}- \\
(-)\end{array}$ & $\begin{array}{l}- \\
(-)\end{array}$ & $\begin{array}{l}- \\
(-)\end{array}$ & $\begin{array}{l}- \\
(-)\end{array}$ & $\begin{array}{l}- \\
(-)\end{array}$ & $\begin{array}{l}- \\
(-)\end{array}$ \\
\hline d_Nordic & $\begin{array}{l}0.0139 \\
(0.489)\end{array}$ & $\begin{array}{c}-0.0503 \\
(0.532)\end{array}$ & $\begin{array}{l}-0.206 \\
(0.288)\end{array}$ & $\begin{array}{l}0.0782 \\
(0.643)\end{array}$ & $\begin{array}{c}0.105 \\
(0.730)\end{array}$ & $\begin{array}{c}0.164 \\
(0.492)\end{array}$ \\
\hline d_Asia & $\begin{array}{c}-2.051^{* * *} \\
(0.719)\end{array}$ & $\begin{array}{c}-2.237^{* * *} \\
(0.678)\end{array}$ & $\begin{array}{c}-2.251^{* * *} \\
(0.701)\end{array}$ & $\begin{array}{c}-1.845^{* *} \\
(0.731)\end{array}$ & $\begin{array}{c}-2.036^{* * *} \\
(0.700)\end{array}$ & $\begin{array}{c}-1.992^{* * *} \\
(0.723)\end{array}$ \\
\hline d_Western_Europe & $\begin{array}{l}- \\
(-)\end{array}$ & $\begin{array}{l}- \\
(-)\end{array}$ & $\begin{array}{l}- \\
(-)\end{array}$ & $\begin{array}{l}- \\
(-)\end{array}$ & $\begin{array}{l}- \\
(-)\end{array}$ & $\begin{array}{l}- \\
(-)\end{array}$ \\
\hline d_1980s & $\begin{array}{c}13.62^{* * *} \\
(1.920)\end{array}$ & $\begin{array}{c}13.10^{* * * *} \\
(1.931)\end{array}$ & $\begin{array}{c}14.94^{* * *} \\
(2.668)\end{array}$ & $\begin{array}{c}91.41 \\
(471.4)\end{array}$ & $\begin{array}{c}59.82 \\
(438.8)\end{array}$ & $\begin{array}{l}24.42^{*} \\
(14.52)\end{array}$ \\
\hline d_1990s & $\begin{array}{c}14.28^{* * * *} \\
(1.115)\end{array}$ & $\begin{array}{c}13.97^{* * *} \\
(1.135)\end{array}$ & $\begin{array}{c}16.12^{* * *} \\
(1.307)\end{array}$ & $\begin{array}{c}90.37 \\
(471.1)\end{array}$ & $\begin{array}{c}58.58 \\
(438.7)\end{array}$ & $\begin{array}{l}23.88 \\
(15.07)\end{array}$ \\
\hline d_2000s & $\begin{array}{c}14.19^{* * *} \\
(0.800)\end{array}$ & $\begin{array}{c}13.74^{* * * *} \\
(0.872)\end{array}$ & $\begin{array}{c}16.11^{* * *} * \\
(1.102)\end{array}$ & $\begin{array}{c}90.76 \\
(471.2)\end{array}$ & $\begin{array}{c}58.86 \\
(438.8)\end{array}$ & $\begin{array}{c}24.31 \\
(15.01)\end{array}$ \\
\hline m2_reserves & & & & $\begin{array}{l}0.00855 \\
(0.0832)\end{array}$ & $\begin{array}{l}-0.0248 \\
(0.0693)\end{array}$ & $\begin{array}{c}0.0703 \\
(0.0709)\end{array}$ \\
\hline credit_gdp & & & & $\begin{array}{c}0.00808 \\
(0.00888)\end{array}$ & $\begin{array}{c}0.00927 \\
(0.0109)\end{array}$ & $\begin{array}{c}0.00764 \\
(0.00702)\end{array}$ \\
\hline L2.credit_growth & & & & $\begin{array}{c}1.061 \\
(6.023)\end{array}$ & $\begin{array}{c}0.660 \\
(5.611)\end{array}$ & $\begin{array}{l}-1.044 \\
(4.391)\end{array}$ \\
\hline L.topincomep99 & $\begin{array}{c}24.44^{* * *} \\
(7.838)\end{array}$ & & & $\begin{array}{c}28.05^{* * *} \\
(9.753)\end{array}$ & & \\
\hline L2.topincomep99 & & $\begin{array}{c}25.91^{* * *} \\
(8.567)\end{array}$ & & & $\begin{array}{c}33.96^{* * *} \\
(12.05)\end{array}$ & \\
\hline L3.topincomep99 & & & $\begin{array}{l}13.60^{*} \\
(7.107)\end{array}$ & & & $\begin{array}{c}23.31^{* *} \\
(9.947)\end{array}$ \\
\hline Observations & 408 & 402 & 392 & 324 & 321 & 317 \\
\hline No. crises & 15 & 15 & 15 & 14 & 14 & 14 \\
\hline \% Total Correct & 96.81 & 96.77 & 96.43 & 96.30 & 96.26 & 95.90 \\
\hline \% Crises Correct & 13.33 & 13.33 & 6.667 & 14.29 & 14.29 & 7.143 \\
\hline$\%$ No-Crises Correct & 100 & 100 & 100 & 100 & 100 & 100 \\
\hline Pseudo R-sq & 0.266 & 0.279 & 0.229 & 0.281 & 0.304 & 0.247 \\
\hline Chi-sq & 34.23 & 35.78 & 29.12 & 32.42 & 34.97 & 28.31 \\
\hline $\mathrm{p}$-value & 0.00506 & 0.00311 & 0.0231 & 0.0280 & 0.0141 & 0.0776 \\
\hline $\mathrm{AIC}$ & 124.3 & 122.3 & 114.2 & 118.9 & 116.1 & 122.4 \\
\hline
\end{tabular}

Robust standard errors in parentheses.

*** $\mathrm{p}<0.01,{ }^{* *} \mathrm{p}<0.05,{ }^{*} \mathrm{p}<0.1$ 
Table A6: Results for the top $0.1 \%, 5 \%$ and $10 \%$ income shares including regional dummies

\begin{tabular}{|c|c|c|c|c|c|c|}
\hline Variables & $\begin{array}{c}(1) \\
\text { crisis }\end{array}$ & $\begin{array}{c}(2) \\
\text { crisis }\end{array}$ & $\begin{array}{c}(3) \\
\text { crisis }\end{array}$ & $\begin{array}{c}(4) \\
\text { crisis }\end{array}$ & $\begin{array}{c}(5) \\
\text { crisis }\end{array}$ & $\begin{array}{c}(6) \\
\text { crisis }\end{array}$ \\
\hline gdp_growth & $\begin{array}{c}-0.296^{* *} \\
(0.144)\end{array}$ & $\begin{array}{c}-0.250^{* * *} \\
(0.0943)\end{array}$ & $\begin{array}{c}-0.324^{* * *} \\
(0.120)\end{array}$ & $\begin{array}{c}-0.263^{* *} \\
(0.127)\end{array}$ & $\begin{array}{c}-0.224^{* *} \\
(0.0902)\end{array}$ & $\begin{array}{c}-0.298^{* * *} \\
(0.114)\end{array}$ \\
\hline totchange & $\begin{array}{c}0.0865^{* * *} \\
(0.0184)\end{array}$ & $\begin{array}{c}0.0952^{* * *} \\
(0.0153)\end{array}$ & $\begin{array}{c}0.102^{* * *} \\
(0.0193)\end{array}$ & $\begin{array}{c}0.0776^{* *} \\
(0.0328)\end{array}$ & $\begin{array}{c}0.0921^{* * *} \\
(0.0174)\end{array}$ & $\begin{array}{c}0.101^{* * * *} \\
(0.0215)\end{array}$ \\
\hline depreciation & $\begin{array}{c}-0.0578^{* * *} \\
(0.0201)\end{array}$ & $\begin{array}{c}-0.0573^{* * *} \\
(0.0165)\end{array}$ & $\begin{array}{c}-0.0567^{* * *} \\
(0.0156)\end{array}$ & $\begin{array}{c}-0.0783^{* *} \\
(0.0336)\end{array}$ & $\begin{array}{c}-0.0725^{* * *} \\
(0.0239)\end{array}$ & $\begin{array}{c}-0.0675^{* * *} \\
(0.0222)\end{array}$ \\
\hline realinterest & $\begin{array}{l}0.150^{* *} \\
(0.0732)\end{array}$ & $\begin{array}{c}0.122^{*} \\
(0.0653)\end{array}$ & $\begin{array}{c}0.0895 \\
(0.0607)\end{array}$ & $\begin{array}{l}0.241^{* *} \\
(0.0951)\end{array}$ & $\begin{array}{c}0.175^{*} \\
(0.0941)\end{array}$ & $\begin{array}{c}0.140^{*} \\
(0.0833)\end{array}$ \\
\hline inflation & $\begin{array}{l}0.00115 \\
(0.0843)\end{array}$ & $\begin{array}{l}0.00646 \\
(0.0780)\end{array}$ & $\begin{array}{l}-0.0657 \\
(0.0770)\end{array}$ & $\begin{array}{c}0.0759 \\
(0.0846)\end{array}$ & $\begin{array}{c}0.0426 \\
(0.0822)\end{array}$ & $\begin{array}{l}-0.0353 \\
(0.0967)\end{array}$ \\
\hline gdp_pc & $\begin{array}{c}0.0166 \\
(0.0119)\end{array}$ & $\begin{array}{c}0.0376^{* *} \\
(0.0173)\end{array}$ & $\begin{array}{l}0.0333^{*} \\
(0.0182)\end{array}$ & $\begin{array}{c}0.0214 \\
(0.0160)\end{array}$ & $\begin{array}{c}0.0497^{* * *} \\
(0.0179)\end{array}$ & $\begin{array}{c}0.0478 * * \\
(0.0209)\end{array}$ \\
\hline d_NA_Australasia & $\begin{array}{c}-2.281^{* *} \\
(0.938)\end{array}$ & $\begin{array}{c}-1.738^{* *} \\
(0.739)\end{array}$ & $\begin{array}{c}-1.624^{* *} \\
(0.816)\end{array}$ & $\begin{array}{c}-1.850^{*} \\
(1.009)\end{array}$ & $\begin{array}{c}-1.478^{*} \\
(0.837)\end{array}$ & $\begin{array}{l}-1.274 \\
(0.888)\end{array}$ \\
\hline d_South_Europe & $\begin{array}{c}0.431 \\
(0.451)\end{array}$ & $\begin{array}{c}0.340 \\
(0.542)\end{array}$ & $\begin{array}{c}0.181 \\
(0.555)\end{array}$ & $\begin{array}{c}0.524 \\
(0.578)\end{array}$ & $\begin{array}{c}0.565 \\
(0.552)\end{array}$ & $\begin{array}{c}0.494 \\
(0.600)\end{array}$ \\
\hline d_East_Europe & $(-)$ & $(-)$ & $\begin{array}{l}- \\
(-)\end{array}$ & $\begin{array}{l}- \\
(-)\end{array}$ & $\begin{array}{l}- \\
(-)\end{array}$ & $\begin{array}{l}- \\
(-)\end{array}$ \\
\hline d_Nordic & $\begin{array}{l}-0.284 \\
(0.354)\end{array}$ & $\begin{array}{c}-0.423 \\
(0.659)\end{array}$ & $\begin{array}{c}-0.0113 \\
(0.477)\end{array}$ & $\begin{array}{c}-0.0507 \\
(0.403)\end{array}$ & $\begin{array}{r}-0.197 \\
(0.839)\end{array}$ & $\begin{array}{c}0.264 \\
(0.640)\end{array}$ \\
\hline d_Asia & $\begin{array}{c}-1.717^{* *} \\
(0.705)\end{array}$ & $\begin{array}{c}-2.099 * * * \\
(0.643)\end{array}$ & $\begin{array}{c}-2.623^{* * *} \\
(0.625)\end{array}$ & $\begin{array}{l}-1.233 \\
(0.909)\end{array}$ & $\begin{array}{c}-1.838^{* * *} \\
(0.649)\end{array}$ & $\begin{array}{c}-2.403^{* * *} \\
(0.665)\end{array}$ \\
\hline d_Western_Europe & $(-)$ & $(-)$ & $(-)$ & $(-)$ & $\begin{array}{l}- \\
(-)\end{array}$ & $(-)$ \\
\hline m2_reserves & & & & $\begin{array}{c}-0.0208 \\
(0.144)\end{array}$ & $\begin{array}{l}0.00277 \\
(0.0156)\end{array}$ & $\begin{array}{l}0.00692 \\
(0.0101)\end{array}$ \\
\hline credit_gdp & & & & $\begin{array}{c}0.00812 \\
(0.00787)\end{array}$ & $\begin{array}{c}0.00804 \\
(0.00902)\end{array}$ & $\begin{array}{c}0.00721 \\
(0.00758)\end{array}$ \\
\hline L2.credit_growth & & & & $\begin{array}{l}-0.0122 \\
(0.0281)\end{array}$ & $\begin{array}{c}-0.00374 \\
(0.0292)\end{array}$ & $\begin{array}{c}0.0156 \\
(0.0266)\end{array}$ \\
\hline L.topincomep999 & $\begin{array}{c}47.83^{* * *} \\
(14.31)\end{array}$ & & & $\begin{array}{c}49.65^{* * *} \\
(13.16)\end{array}$ & & \\
\hline L.topincomep95 & & $\begin{array}{c}16.25^{* * *} \\
(5.999)\end{array}$ & & & $\begin{array}{c}20.38 * * \\
(8.681)\end{array}$ & \\
\hline L.topincomep90 & & & $\begin{array}{c}12.47^{* *} \\
(5.660)\end{array}$ & & & $\begin{array}{c}15.91^{* * *} \\
(8.006)\end{array}$ \\
\hline Observations & 366 & 410 & 408 & 287 & 326 & 324 \\
\hline No. crises & 13 & 14 & 15 & 12 & 13 & 14 \\
\hline$\%$ Total Correct & 96.72 & 96.83 & 96.81 & 96.17 & 96.32 & 96.30 \\
\hline$\%$ Crises Correct & 7.692 & 7.143 & 13.33 & 8.333 & 7.692 & 14.29 \\
\hline$\%$ No-Crises Correct & 100 & 100 & 100 & 100 & 100 & 100 \\
\hline Pseudo $\mathrm{R}-\mathrm{sq}$ & 0.241 & 0.208 & 0.234 & 0.250 & 0.224 & 0.249 \\
\hline Chi-sq & 27.05 & 25.41 & 30.08 & 24.91 & 24.44 & 28.67 \\
\hline $\mathrm{p}$-value & 0.0123 & 0.0204 & 0.00459 & 0.0715 & 0.0804 & 0.0263 \\
\hline $\mathrm{AIC}$ & 109.3 & 120.7 & 122.5 & 102.8 & 114.8 & 116.7 \\
\hline
\end{tabular}

Robust standard errors in parentheses.

*** $\mathrm{p}<0.01, * * \mathrm{p}<0.05, * \mathrm{p}<0.1$ 
Table A7: Results for Gini index, excluding one region at a time

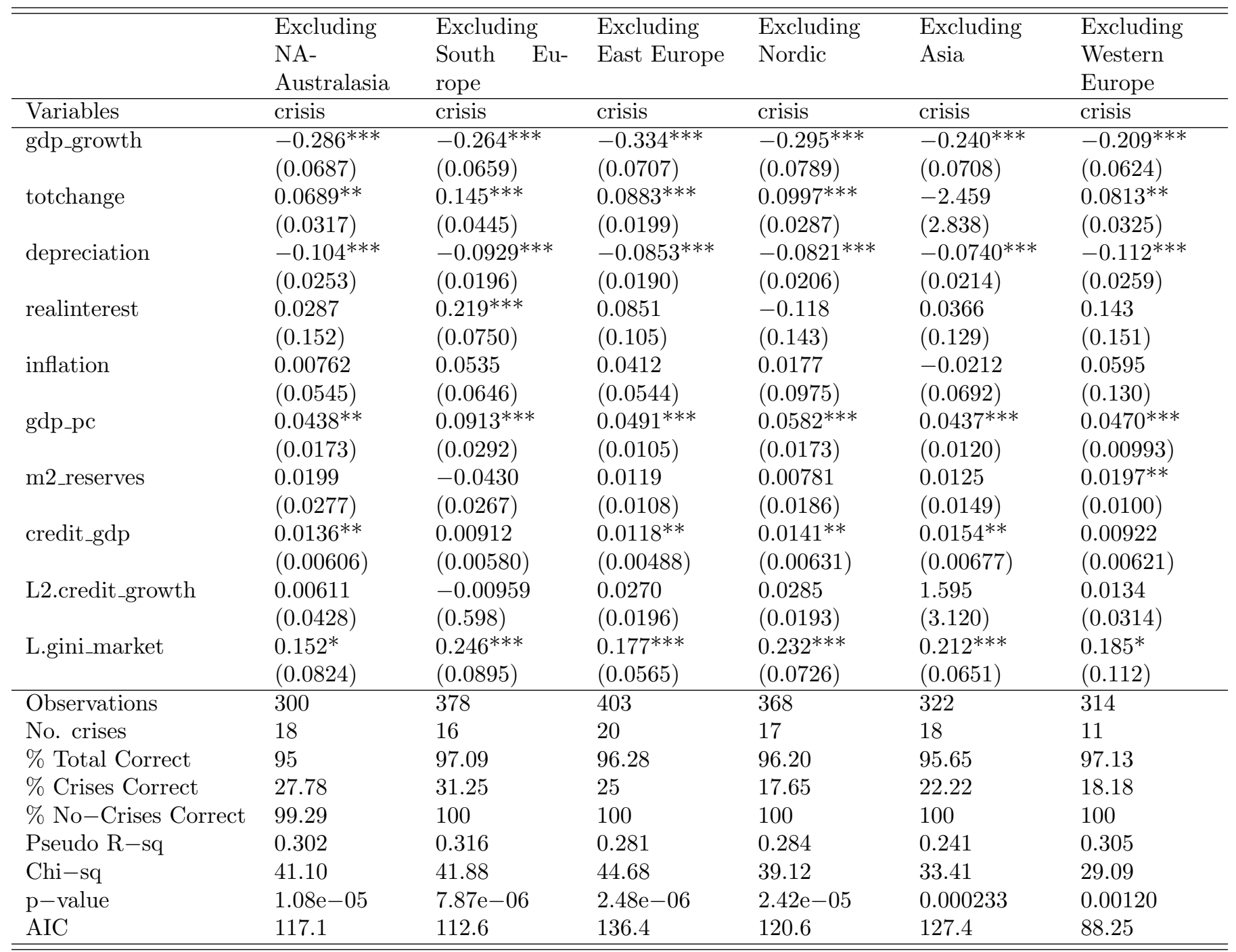

Robust standard errors in parentheses.

*** $\mathrm{p}<0.01,{ }^{*} * \mathrm{p}<0.05,{ }^{*} \mathrm{p}<0.1$ 
Table A8: Results for top 1\% income share, excluding one region at a time

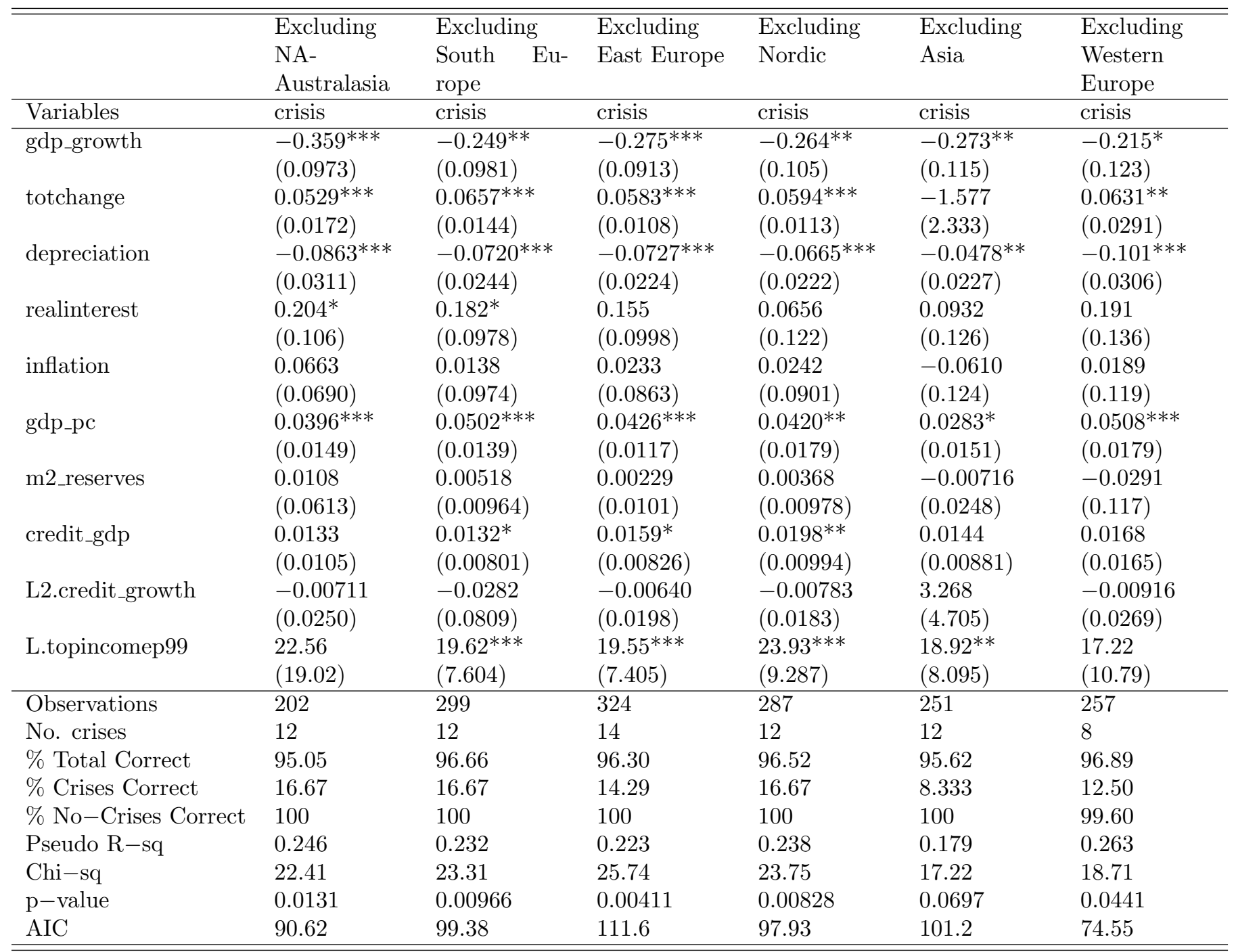

Robust standard errors in parentheses.

*** $\mathrm{p}<0.01, * * \mathrm{p}<0.05, * \mathrm{p}<0.1$ 
Table A9: Income inequality and different measures of credit

\begin{tabular}{|c|c|c|c|c|c|c|}
\hline & (1) & $(2)$ & $(3)$ & (4) & $(5)$ & $(6)$ \\
\hline Variables & crisis & crisis & crisis & crisis & crisis & crisis \\
\hline gdp_growth & $\begin{array}{c}-0.307^{* * *} \\
(0.0732)\end{array}$ & $\begin{array}{c}-0.324^{* * *} \\
(0.0709)\end{array}$ & $\begin{array}{c}-0.322^{* * *} \\
(0.0730)\end{array}$ & $\begin{array}{c}-0.237^{* *} \\
(0.101)\end{array}$ & $\begin{array}{c}-0.279^{* * *} \\
(0.0982)\end{array}$ & $\begin{array}{c}-0.251^{* * *} \\
(0.0846)\end{array}$ \\
\hline totchange & $\begin{array}{c}0.0746^{* * *} \\
(0.0222)\end{array}$ & $\begin{array}{c}0.0832^{* * *} \\
(0.0216)\end{array}$ & $\begin{array}{c}0.0748^{* * *} \\
(0.0232)\end{array}$ & $\begin{array}{c}0.0517^{* * *} \\
(0.0110)\end{array}$ & $\begin{array}{c}0.0613^{* * *} \\
(0.0126)\end{array}$ & $\begin{array}{c}0.0472^{* * *} \\
(0.0149)\end{array}$ \\
\hline depreciation & $\begin{array}{c}-0.0815^{* * *} \\
(0.0209)\end{array}$ & $\begin{array}{c}-0.0878^{* * *} \\
(0.0193)\end{array}$ & $\begin{array}{c}-0.0844^{* * *} \\
(0.0197)\end{array}$ & $\begin{array}{c}-0.0789^{* * *} \\
(0.0249)\end{array}$ & $\begin{array}{c}-0.0855^{* * *} \\
(0.0211)\end{array}$ & $\begin{array}{c}-0.0898^{* * *} \\
(0.0226)\end{array}$ \\
\hline realinterest & $\begin{array}{l}0.0557 \\
(0.122)\end{array}$ & $\begin{array}{c}0.0686 \\
(0.118)\end{array}$ & $\begin{array}{l}0.0357 \\
(0.107)\end{array}$ & $\begin{array}{c}0.156 \\
(0.104)\end{array}$ & $\begin{array}{c}0.128 \\
(0.0903)\end{array}$ & $\begin{array}{c}0.128 \\
(0.0862)\end{array}$ \\
\hline inflation & $\begin{array}{c}0.0124 \\
(0.0640)\end{array}$ & $\begin{array}{l}-0.0176 \\
(0.0704)\end{array}$ & $\begin{array}{l}-0.0549 \\
(0.0683)\end{array}$ & $\begin{array}{c}0.0191 \\
(0.0926)\end{array}$ & $\begin{array}{l}-0.0521 \\
(0.0804)\end{array}$ & $\begin{array}{l}-0.0563 \\
(0.0948)\end{array}$ \\
\hline gdp_pc & $\begin{array}{c}0.0243 \\
(0.0151)\end{array}$ & $\begin{array}{c}0.0416^{* * *} \\
(0.00867)\end{array}$ & $\begin{array}{c}0.0386^{* *} \\
(0.0178)\end{array}$ & $\begin{array}{c}0.0302^{* *} \\
(0.0127)\end{array}$ & $\begin{array}{c}0.0437^{* * *} \\
(0.0167)\end{array}$ & $\begin{array}{c}0.0446^{* *} \\
(0.0210)\end{array}$ \\
\hline m2_reserves & $\begin{array}{c}0.00626 \\
(0.0206)\end{array}$ & $\begin{array}{c}0.0151^{*} \\
(0.00904)\end{array}$ & $\begin{array}{c}0.00919 \\
(0.0136)\end{array}$ & $\begin{array}{c}-0.00272 \\
(0.0228)\end{array}$ & $\begin{array}{c}0.00353 \\
(0.00845)\end{array}$ & $\begin{array}{l}0.00192 \\
(0.0117)\end{array}$ \\
\hline totalcredit_gdp & $\begin{array}{l}0.0105^{* *} \\
(0.00515)\end{array}$ & & & $\begin{array}{l}0.0193^{* *} \\
(0.00945)\end{array}$ & & \\
\hline L2.totalcredit_growth & $\begin{array}{c}0.00926 \\
(0.0170)\end{array}$ & & & $\begin{array}{c}-0.0110 \\
(0.0173)\end{array}$ & & \\
\hline hhcredit_gdp & & $\begin{array}{c}0.0283^{* * *} \\
(0.00907)\end{array}$ & & & $\begin{array}{l}0.0270^{*} \\
(0.0157)\end{array}$ & \\
\hline L2.hhcredit_growth & & $\begin{array}{c}0.0532^{* *} \\
(0.0239)\end{array}$ & & & $\begin{array}{c}0.0171 \\
(0.0292)\end{array}$ & \\
\hline firmcredit_gdp & & & $\begin{array}{c}0.00270 \\
(0.00592)\end{array}$ & & & $\begin{array}{c}0.0156 \\
(0.0101)\end{array}$ \\
\hline L2.firmcredit_growth & & & $\begin{array}{c}0.000698 \\
(0.0272)\end{array}$ & & & $\begin{array}{c}-0.00740 \\
(0.0132)\end{array}$ \\
\hline L.gini_market & $\begin{array}{c}0.154^{* * *} \\
(0.0528)\end{array}$ & $\begin{array}{l}0.140^{* *} \\
(0.0544)\end{array}$ & $\begin{array}{l}0.132^{* *} \\
(0.0567)\end{array}$ & & & \\
\hline L.topincomep99 & & & & $\begin{array}{c}17.03^{* * *} \\
(5.132)\end{array}$ & $\begin{array}{l}9.210^{* *} \\
(4.068)\end{array}$ & $\begin{array}{c}16.34^{* * *} \\
(6.145)\end{array}$ \\
\hline Observations & 409 & 388 & 372 & 324 & 298 & 289 \\
\hline No. crises & 19 & 19 & 19 & 14 & 14 & 14 \\
\hline \% Total Correct & 96.33 & 95.88 & 95.70 & 96.30 & 95.97 & 95.85 \\
\hline \% Crises Correct & 21.05 & 15.79 & 15.79 & 14.29 & 14.29 & 14.29 \\
\hline$\%$ No-Crises Correct & 100 & 100 & 100 & 100 & 100 & 100 \\
\hline Pseudo R-sq & 0.256 & 0.271 & 0.234 & 0.236 & 0.241 & 0.229 \\
\hline Chi-sq & 39.39 & 41.05 & 35.14 & 27.20 & 27.22 & 25.66 \\
\hline $\mathrm{p}$-value & $2.17 \mathrm{e}-05$ & $1.11 \mathrm{e}-05$ & 0.000118 & 0.00242 & 0.00240 & 0.00422 \\
\hline $\mathrm{AIC}$ & 136.3 & 132.6 & 136.9 & 110.2 & 107.7 & 108.4 \\
\hline
\end{tabular}

Robust standard errors in parentheses.

*** $\mathrm{p}<0.01,{ }^{* *} \mathrm{p}<0.05,{ }^{*} \mathrm{p}<0.1$ 
Table A10: Gini index, all control variables are lagged 1 period

\begin{tabular}{|c|c|c|c|c|c|c|}
\hline Variables & $\begin{array}{l}(1) \\
\text { crisis }\end{array}$ & $\begin{array}{c}(2) \\
\text { crisis }\end{array}$ & $\begin{array}{c}(3) \\
\text { crisis }\end{array}$ & $\begin{array}{c}(4) \\
\text { crisis }\end{array}$ & $\begin{array}{c}(5) \\
\text { crisis }\end{array}$ & $\begin{array}{c}(6) \\
\text { crisis }\end{array}$ \\
\hline \multirow[t]{2}{*}{ L.gdp_growth } & $0.141^{* * *}$ & $0.143^{* * *}$ & $0.143^{* * *}$ & $0.260^{* *}$ & $0.236^{* *}$ & $0.220^{* *}$ \\
\hline & $(0.0513)$ & $(0.0521)$ & $(0.0513)$ & $(0.103)$ & $(0.0989)$ & $(0.0989)$ \\
\hline \multirow{2}{*}{ L.totchange } & $0.0888^{* * *}$ & $0.0899 * * *$ & $0.0872^{* * *}$ & $0.145^{* * *}$ & $0.147^{* * *}$ & $0.148^{* * *}$ \\
\hline & $(0.0182)$ & $(0.0182)$ & $(0.0176)$ & $(0.0374)$ & $(0.0395)$ & $(0.0391)$ \\
\hline \multirow{2}{*}{ L.depreciation } & -0.0215 & -0.0226 & -0.0233 & -0.0478 & -0.0506 & -0.0503 \\
\hline & $(0.0218)$ & $(0.0223)$ & $(0.0226)$ & $(0.0327)$ & $(0.0337)$ & $(0.0342)$ \\
\hline \multirow[t]{2}{*}{ L.realinterest } & $0.178^{* *}$ & $0.181^{* *}$ & $0.186^{* *}$ & $0.378^{* * *}$ & $0.407^{* * *}$ & $0.423^{* * *}$ \\
\hline & $(0.0831)$ & $(0.0815)$ & $(0.0804)$ & $(0.102)$ & $(0.120)$ & $(0.130)$ \\
\hline \multirow{2}{*}{ L.inflation } & 0.101 & 0.103 & 0.110 & 0.0488 & 0.0614 & 0.0742 \\
\hline & $(0.0729)$ & $(0.0733)$ & $(0.0718)$ & $(0.104)$ & $(0.108)$ & $(0.109)$ \\
\hline \multirow[t]{2}{*}{ L.gdp_pc } & $0.0343^{* * *}$ & $0.0345^{* * *}$ & $0.0343^{* * *}$ & $0.0687^{* *}$ & $0.0705^{* *}$ & $0.0716^{* *}$ \\
\hline & $(0.0128)$ & $(0.0129)$ & $(0.0130)$ & $(0.0283)$ & $(0.0303)$ & $(0.0307)$ \\
\hline \multirow{2}{*}{ d_NA_Australasia } & -1.366 & -1.339 & -1.323 & -0.834 & -0.879 & -0.807 \\
\hline & $(1.053)$ & $(1.038)$ & $(1.022)$ & $(1.280)$ & $(1.293)$ & $(1.220)$ \\
\hline \multirow[t]{2}{*}{ d_South_Europe } & 0.376 & 0.340 & 0.319 & $1.861^{* * *}$ & $1.871^{* * *}$ & $1.879^{* * *}$ \\
\hline & $(0.823)$ & $(0.833)$ & $(0.829)$ & $(0.586)$ & $(0.576)$ & $(0.566)$ \\
\hline \multirow[t]{2}{*}{ d_East_Europe } & 0.409 & 0.443 & 0.468 & - & - & - \\
\hline & $(0.752)$ & $(0.751)$ & $(0.732)$ & $(-)$ & $(-)$ & $(-)$ \\
\hline \multirow[t]{2}{*}{ d_Nordic } & -0.539 & -0.529 & -0.558 & -0.706 & -0.897 & -0.971 \\
\hline & $(0.525)$ & $(0.531)$ & $(0.541)$ & $(0.549)$ & $(0.637)$ & $(0.700)$ \\
\hline \multirow[t]{2}{*}{ d_Asia } & -2.017 & -2.040 & -2.032 & $-2.163^{*}$ & $-2.253^{*}$ & $-2.293^{*}$ \\
\hline & $(1.250)$ & $(1.277)$ & $(1.291)$ & $(1.243)$ & $(1.284)$ & $(1.314)$ \\
\hline \multirow[t]{2}{*}{ d_Western_Europe } & - & - & - & - & - & - \\
\hline & $(-)$ & $(-)$ & $(-)$ & $(-)$ & $(-)$ & $(-)$ \\
\hline \multirow[t]{2}{*}{ L.m2_reserves } & & & & -0.0188 & -0.0198 & -0.0196 \\
\hline & & & & $(0.0269)$ & $(0.0289)$ & $(0.0290)$ \\
\hline \multirow[t]{2}{*}{ L.credit_gdp } & & & & $0.0156^{* * *}$ & $0.0164^{* * *}$ & $0.0168^{* * *}$ \\
\hline & & & & $(0.00399)$ & $(0.00411)$ & $(0.00438)$ \\
\hline \multirow[t]{2}{*}{ L.credit_growth } & & & & -4.416 & -4.813 & -4.969 \\
\hline & & & & $(3.428)$ & $(3.650)$ & $(3.824)$ \\
\hline \multirow[t]{2}{*}{ L.gini_market } & $0.0892^{* *}$ & & & $0.184^{* *}$ & & \\
\hline & $(0.0369)$ & & & $(0.0922)$ & & \\
\hline \multirow[t]{2}{*}{ L2.gini_market } & & $0.0939^{* *}$ & & & $0.173^{* *}$ & \\
\hline & & $(0.0378)$ & & & $(0.0874)$ & \\
\hline \multirow[t]{2}{*}{ L3.gini_market } & & & $0.0891^{* *}$ & & & $0.172^{* *}$ \\
\hline & & & $(0.0406)$ & & & $(0.0787)$ \\
\hline Observations & 569 & 563 & 550 & 391 & 386 & 379 \\
\hline No. crises & 24 & 24 & 24 & 20 & 20 & 20 \\
\hline \% Total Correct & 95.96 & 95.91 & 95.82 & 95.65 & 95.60 & 95.51 \\
\hline \% Crises Correct & 4.167 & 4.167 & 4.167 & 15 & 15 & 15 \\
\hline$\%$ No-Crises Correct & 100 & 100 & 100 & 100 & 100 & 100 \\
\hline Pseudo R-sq & 0.145 & 0.147 & 0.145 & 0.270 & 0.272 & 0.274 \\
\hline Chi-sq & 28.92 & 29.16 & 28.63 & 42.60 & 42.80 & 42.84 \\
\hline $\mathrm{p}$-value & 0.00671 & 0.00620 & 0.00739 & 0.000321 & 0.000300 & 0.000296 \\
\hline AIC & 196 & 195.2 & 194.6 & 145.3 & 144.6 & 143.8 \\
\hline
\end{tabular}

Robust standard errors in parentheses.

$* * * \mathrm{p}<0.01,{ }^{* *} \mathrm{p}<0.05,{ }^{*} \mathrm{p}<0.1$ 
Table A11: Top 1\% income share, all control variables are lagged 1 period

\begin{tabular}{|c|c|c|c|c|c|c|}
\hline Variables & $\begin{array}{l}(1) \\
\text { crisis }\end{array}$ & $\begin{array}{c}(2) \\
\text { crisis }\end{array}$ & $\begin{array}{c}(3) \\
\text { crisis }\end{array}$ & $\begin{array}{l}(4) \\
\text { crisis }\end{array}$ & $\begin{array}{c}(5) \\
\text { crisis }\end{array}$ & $\begin{array}{c}(6) \\
\text { crisis }\end{array}$ \\
\hline L.gdp_growth & 0.0837 & 0.119 & 0.112 & 0.224 & $0.284^{* *}$ & $0.267^{* *}$ \\
\hline & $(0.0762)$ & $(0.0833)$ & $(0.0836)$ & $(0.138)$ & $(0.130)$ & $(0.124)$ \\
\hline L.totchange & $\begin{array}{c}0.0997 * * * \\
(0.0162)\end{array}$ & $\begin{array}{c}0.122^{* * *} \\
(0.0203)\end{array}$ & $\begin{array}{c}0.0808^{* *} \\
(0.0359)\end{array}$ & $\begin{array}{c}0.0998^{* * *} \\
(0.0162)\end{array}$ & $\begin{array}{c}0.126^{* * *} \\
(0.0220)\end{array}$ & $\begin{array}{c}0.0895^{* *} \\
(0.0377)\end{array}$ \\
\hline L.depreciation & $\begin{array}{l}-0.0261 \\
(0.0342)\end{array}$ & $\begin{array}{l}-0.0217 \\
(0.0333)\end{array}$ & $\begin{array}{l}-0.0298 \\
(0.0338)\end{array}$ & $\begin{array}{c}-0.0363 \\
(0.0373)\end{array}$ & $\begin{array}{l}-0.0324 \\
(0.0366)\end{array}$ & $\begin{array}{l}-0.0356 \\
(0.0359)\end{array}$ \\
\hline L.realinterest & $\begin{array}{c}0.270^{* * *} \\
(0.0967)\end{array}$ & $\begin{array}{c}0.273^{* * *} \\
(0.0924)\end{array}$ & $\begin{array}{l}0.218^{* *} \\
(0.0889)\end{array}$ & $\begin{array}{c}0.462^{\text {*** }} \\
(0.150)\end{array}$ & $\begin{array}{c}0.426^{* * *} \\
(0.127)\end{array}$ & $\begin{array}{c}0.418^{* * *} \\
(0.129)\end{array}$ \\
\hline L.inflation & $\begin{array}{c}0.0718 \\
(0.0741)\end{array}$ & $\begin{array}{c}0.0972 \\
(0.0774)\end{array}$ & $\begin{array}{c}0.0510 \\
(0.0796)\end{array}$ & $\begin{array}{c}0.172 \\
(0.132)\end{array}$ & $\begin{array}{c}0.181 \\
(0.125)\end{array}$ & $\begin{array}{c}0.186 \\
(0.143)\end{array}$ \\
\hline L.gdp_pc & $\begin{array}{l}0.0408^{*} \\
(0.0228)\end{array}$ & $\begin{array}{c}0.0394^{*} \\
(0.0238)\end{array}$ & $\begin{array}{l}0.0331^{*} \\
(0.0198)\end{array}$ & $\begin{array}{l}0.0395^{*} \\
(0.0217)\end{array}$ & $\begin{array}{c}0.0365 \\
(0.0233)\end{array}$ & $\begin{array}{l}0.0350^{*} \\
(0.0197)\end{array}$ \\
\hline d_NA_Australasia & $\begin{array}{c}-2.383^{* * *} \\
(0.725)\end{array}$ & $\begin{array}{c}-2.585^{* * *} \\
(0.674)\end{array}$ & $\begin{array}{c}-2.138^{* * *} \\
(0.756)\end{array}$ & $\begin{array}{c}-1.867^{* *} \\
(0.877)\end{array}$ & $\begin{array}{c}-2.096^{* *} \\
(0.833)\end{array}$ & $\begin{array}{c}-1.929^{* *} \\
(0.923)\end{array}$ \\
\hline d_South_Europe & $\begin{array}{c}1.012 \\
(0.621)\end{array}$ & $\begin{array}{c}0.898 \\
(0.669)\end{array}$ & $\begin{array}{c}1.056^{* *} \\
(0.532)\end{array}$ & $\begin{array}{l}1.611^{*} \\
(0.946)\end{array}$ & $\begin{array}{c}1.425 \\
(0.960)\end{array}$ & $\begin{array}{c}1.535^{* *} \\
(0.767)\end{array}$ \\
\hline d_East_Europe & $\begin{array}{l}- \\
(-)\end{array}$ & $\begin{array}{l}- \\
(-)\end{array}$ & $\begin{array}{l}- \\
(-)\end{array}$ & $\begin{array}{l}- \\
(-)\end{array}$ & $\begin{array}{l}- \\
(-)\end{array}$ & $\begin{array}{l}- \\
(-)\end{array}$ \\
\hline d_Nordic & $\begin{array}{c}-0.715 \\
(0.890)\end{array}$ & $\begin{array}{c}-0.758 \\
(0.907)\end{array}$ & $\begin{array}{l}-0.888 \\
(0.758)\end{array}$ & $\begin{array}{c}0.405 \\
(0.846)\end{array}$ & $\begin{array}{c}0.372 \\
(0.887)\end{array}$ & $\begin{array}{c}0.274 \\
(0.718)\end{array}$ \\
\hline d_Asia & $\begin{array}{c}-2.191^{* *} \\
(0.933)\end{array}$ & $\begin{array}{c}-2.723^{* *} \\
(1.222)\end{array}$ & $\begin{array}{c}-2.377^{* *} \\
(0.989)\end{array}$ & $\begin{array}{c}-2.153^{* *} \\
(0.911)\end{array}$ & $\begin{array}{c}-2.907^{* *} \\
(1.418)\end{array}$ & $\begin{array}{c}-2.614^{* *} \\
(1.332)\end{array}$ \\
\hline d_Western_Europe & $\begin{array}{l}- \\
(-)\end{array}$ & $\begin{array}{l}- \\
(-)\end{array}$ & $\begin{array}{l}- \\
(-)\end{array}$ & $\begin{array}{l}- \\
(-)\end{array}$ & $\begin{array}{l}- \\
(-)\end{array}$ & $\begin{array}{l}- \\
(-)\end{array}$ \\
\hline L.m2_reserves & & & & $\begin{array}{c}0.0134 \\
(0.0146)\end{array}$ & $\begin{array}{c}0.00854 \\
(0.0183)\end{array}$ & $\begin{array}{c}0.0125 \\
(0.0127)\end{array}$ \\
\hline L.credit_gdp & & & & $\begin{array}{l}0.0203^{*} \\
(0.0115)\end{array}$ & $\begin{array}{c}0.0173 \\
(0.0113)\end{array}$ & $\begin{array}{c}0.0183^{* *} \\
(0.00911)\end{array}$ \\
\hline L.credit_growth & & & & $\begin{array}{l}-6.574 \\
(5.588)\end{array}$ & $\begin{array}{l}-6.676 \\
(5.405)\end{array}$ & $\begin{array}{l}-6.627 \\
(5.076)\end{array}$ \\
\hline L.topincomep99 & $\begin{array}{c}27.09^{* * *} \\
(7.588)\end{array}$ & & & $\begin{array}{c}33.02^{* * *} \\
(9.172)\end{array}$ & & \\
\hline L2.topincomep99 & & $\begin{array}{c}30.73^{* * *} \\
(9.277)\end{array}$ & & & $\begin{array}{c}35.90^{* * *} \\
(10.78)\end{array}$ & \\
\hline L3.topincomep99 & & & $\begin{array}{c}20.55^{* *} \\
(8.221)\end{array}$ & & & $\begin{array}{c}30.57^{* * *} \\
(10.77)\end{array}$ \\
\hline Observations & 395 & 392 & 386 & 316 & 314 & 307 \\
\hline No. crises & 15 & 15 & 15 & 14 & 14 & 14 \\
\hline \% Total Correct & 96.20 & 96.43 & 96.11 & 96.20 & 96.50 & 95.77 \\
\hline \% Crises Correct & 0 & 6.667 & 0 & 14.29 & 21.43 & 7.143 \\
\hline$\%$ No-Crises Correct & 100 & 100 & 100 & 100 & 100 & 100 \\
\hline Pseudo R-sq & 0.192 & 0.216 & 0.154 & 0.235 & 0.255 & 0.208 \\
\hline Chi-sq & 24.49 & 27.52 & 19.56 & 26.92 & 29.16 & 23.71 \\
\hline $\mathrm{p}$-value & 0.0269 & 0.0106 & 0.107 & 0.0423 & 0.0229 & 0.0961 \\
\hline $\mathrm{AIC}$ & 127.1 & 123.8 & 131.3 & 117.7 & 115.3 & 120.1 \\
\hline
\end{tabular}

Robust standard errors in parentheses.

*** $\mathrm{p}<0.01,{ }^{* *} \mathrm{p}<0.05,{ }^{*} \mathrm{p}<0.1$ 
Table A12: Logit results for income inequality, robust S.E. (not clustered by country)

\begin{tabular}{|c|c|c|c|c|c|c|}
\hline Variables & $\begin{array}{l}(1) \\
\text { crisis }\end{array}$ & $\begin{array}{l}(2) \\
\text { crisis }\end{array}$ & $\begin{array}{l}(3) \\
\text { crisis }\end{array}$ & $\begin{array}{l}(4) \\
\text { crisis }\end{array}$ & $\begin{array}{l}(5) \\
\text { crisis }\end{array}$ & $\begin{array}{l}(6) \\
\text { crisis }\end{array}$ \\
\hline gdp_growth & $\begin{array}{c}-0.181^{* * *} \\
(0.0508)\end{array}$ & $\begin{array}{c}-0.265^{* * *} \\
(0.0579)\end{array}$ & $\begin{array}{c}-0.324^{* * *} \\
(0.0718)\end{array}$ & $\begin{array}{c}-0.308^{* * *} \\
(0.0953)\end{array}$ & $\begin{array}{c}-0.275^{* * *} \\
(0.0881)\end{array}$ & $\begin{array}{c}-0.279^{* * *} \\
(0.0967)\end{array}$ \\
\hline totchange & $\begin{array}{c}0.0622^{* * *} \\
(0.0171)\end{array}$ & $\begin{array}{c}0.0845^{* * *} \\
(0.0254)\end{array}$ & $\begin{array}{c}0.0832^{* * *} \\
(0.0286)\end{array}$ & $\begin{array}{c}0.0630^{* * *} \\
(0.0177)\end{array}$ & $\begin{array}{c}0.0583^{* * *} \\
(0.0192)\end{array}$ & $\begin{array}{c}0.0613^{* * *} \\
(0.0206)\end{array}$ \\
\hline depreciation & $\begin{array}{c}-0.0739^{* * *} \\
(0.0178)\end{array}$ & $\begin{array}{c}-0.0885^{* * *} \\
(0.0206)\end{array}$ & $\begin{array}{c}-0.0878^{* * *} \\
(0.0208)\end{array}$ & $\begin{array}{c}-0.0689^{* * *} \\
(0.0205)\end{array}$ & $\begin{array}{c}-0.0727^{* * *} \\
(0.0193)\end{array}$ & $\begin{array}{c}-0.0855^{* * *} \\
(0.0213)\end{array}$ \\
\hline realinterest & $\begin{array}{c}0.0306 \\
(0.0766)\end{array}$ & $\begin{array}{l}0.0616 \\
(0.121)\end{array}$ & $\begin{array}{c}0.0686 \\
(0.128)\end{array}$ & $\begin{array}{c}0.0823 \\
(0.0859)\end{array}$ & $\begin{array}{c}0.155 \\
(0.117)\end{array}$ & $\begin{array}{c}0.128 \\
(0.123)\end{array}$ \\
\hline inflation & $\begin{array}{c}0.0664 \\
(0.0663)\end{array}$ & $\begin{array}{c}0.0311 \\
(0.0751)\end{array}$ & $\begin{array}{l}-0.0176 \\
(0.0923)\end{array}$ & $\begin{array}{c}-0.0692 \\
(0.0840)\end{array}$ & $\begin{array}{c}0.0233 \\
(0.101)\end{array}$ & $\begin{array}{r}-0.0521 \\
(0.0996)\end{array}$ \\
\hline gdp_pc & $\begin{array}{c}0.0293^{* * *} \\
(0.00989)\end{array}$ & $\begin{array}{c}0.0500^{* * *} \\
(0.0153)\end{array}$ & $\begin{array}{c}0.0416^{* * *} \\
(0.0140)\end{array}$ & $\begin{array}{c}0.0369^{* *} \\
(0.0147)\end{array}$ & $\begin{array}{c}0.0426^{* *} \\
(0.0180)\end{array}$ & $\begin{array}{c}0.0437^{* *} \\
(0.0190)\end{array}$ \\
\hline m2_reserves & & $\begin{array}{c}0.0107 \\
(0.0140)\end{array}$ & $\begin{array}{c}0.0151^{*} \\
(0.00866)\end{array}$ & & $\begin{array}{c}0.00229 \\
(0.0101)\end{array}$ & $\begin{array}{c}0.00353 \\
(0.00894)\end{array}$ \\
\hline credit_gdp & & $\begin{array}{c}0.0123^{* *} \\
(0.00618)\end{array}$ & & & $\begin{array}{c}0.0159 \\
(0.0122)\end{array}$ & \\
\hline L2.credit_growth & & $\begin{array}{c}0.0175 \\
(0.0228)\end{array}$ & & & $\begin{array}{c}-0.00640 \\
(0.0218)\end{array}$ & \\
\hline hhcredit_gdp & & & $\begin{array}{c}0.0283^{* *} \\
(0.0137)\end{array}$ & & & $\begin{array}{c}0.0270 \\
(0.0189)\end{array}$ \\
\hline L2.hhcredit_growth & & & $\begin{array}{l}0.0532^{*} \\
(0.0278)\end{array}$ & & & $\begin{array}{c}0.0171 \\
(0.0323)\end{array}$ \\
\hline L.gini_market & $\begin{array}{c}0.118^{* *} \\
(0.0471)\end{array}$ & $\begin{array}{c}0.180^{* *} \\
(0.0713)\end{array}$ & $\begin{array}{c}0.140^{*} \\
(0.0792)\end{array}$ & & & \\
\hline L.topincomep99 & & & & $\begin{array}{c}12.82 \\
(8.785)\end{array}$ & $\begin{array}{l}19.55^{*} \\
(11.77)\end{array}$ & $\begin{array}{c}9.210 \\
(7.648)\end{array}$ \\
\hline Observations & 588 & 417 & 388 & 408 & 324 & 298 \\
\hline No. crises & 24 & 20 & 19 & 15 & 14 & 14 \\
\hline$\%$ Total Correct & 96.09 & 96.40 & 95.88 & 96.57 & 96.30 & 95.97 \\
\hline \% Crises Correct & 8.333 & 25 & 15.79 & 6.667 & 14.29 & 14.29 \\
\hline$\%$ No-Crises Correct & 99.82 & 100 & 100 & 100 & 100 & 100 \\
\hline Pseudo R-sq & 0.178 & 0.275 & 0.271 & 0.195 & 0.223 & 0.241 \\
\hline Chi-sq & 35.72 & 44.16 & 41.05 & 25.04 & 25.74 & 27.22 \\
\hline $\mathrm{p}$-value & $8.20 \mathrm{e}-06$ & $3.08 \mathrm{e}-06$ & $1.11 \mathrm{e}-05$ & 0.000748 & 0.00411 & 0.00240 \\
\hline AIC & 180.8 & 138.4 & 132.6 & 119.5 & 111.6 & 107.7 \\
\hline
\end{tabular}

Robust standard errors in parentheses.

*** $\mathrm{p}<0.01,{ }^{* *} \mathrm{p}<0.05,{ }^{*} \mathrm{p}<0.1$ 
Table A13: Probit results for income inequality, robust S.E. (not clustered by country)

\begin{tabular}{|c|c|c|c|c|c|c|}
\hline Variables & $\begin{array}{l}(1) \\
\text { crisis }\end{array}$ & $\begin{array}{l}(2) \\
\text { crisis }\end{array}$ & $\begin{array}{l}(3) \\
\text { crisis }\end{array}$ & $\begin{array}{l}(4) \\
\text { crisis }\end{array}$ & $\begin{array}{l}(5) \\
\text { crisis }\end{array}$ & $\begin{array}{l}(6) \\
\text { crisis }\end{array}$ \\
\hline gdp_growth & $\begin{array}{c}-0.0946^{* * *} \\
(0.0272)\end{array}$ & $\begin{array}{c}-0.140^{* * *} \\
(0.0353)\end{array}$ & $\begin{array}{c}-0.171^{* * *} \\
(0.0445)\end{array}$ & $\begin{array}{c}-0.156^{* * *} \\
(0.0507)\end{array}$ & $\begin{array}{c}-0.139^{* * *} \\
(0.0493)\end{array}$ & $\begin{array}{c}-0.145^{* * *} \\
(0.0539)\end{array}$ \\
\hline totchange & $\begin{array}{c}0.0309^{* * *} \\
(0.00904)\end{array}$ & $\begin{array}{c}0.0432^{* * *} \\
(0.0132)\end{array}$ & $\begin{array}{c}0.0402^{* * *} \\
(0.0143)\end{array}$ & $\begin{array}{c}0.0321^{* * *} \\
(0.0102)\end{array}$ & $\begin{array}{c}0.0295^{* * *} \\
(0.0104)\end{array}$ & $\begin{array}{c}0.0302^{* * *} \\
(0.0105)\end{array}$ \\
\hline depreciation & $\begin{array}{c}-0.0356^{* * *} \\
(0.00882)\end{array}$ & $\begin{array}{c}-0.0451^{* * *} \\
(0.0101)\end{array}$ & $\begin{array}{c}-0.0471^{* * *} \\
(0.0108)\end{array}$ & $\begin{array}{c}-0.0325^{* * *} \\
(0.0102)\end{array}$ & $\begin{array}{c}-0.0381^{* * *} \\
(0.00956)\end{array}$ & $\begin{array}{c}-0.0458^{* * *} \\
(0.0110)\end{array}$ \\
\hline realinterest & $\begin{array}{c}0.0263 \\
(0.0357)\end{array}$ & $\begin{array}{c}0.0508 \\
(0.0534)\end{array}$ & $\begin{array}{c}0.0425 \\
(0.0582)\end{array}$ & $\begin{array}{c}0.0427 \\
(0.0399)\end{array}$ & $\begin{array}{c}0.0868 \\
(0.0552)\end{array}$ & $\begin{array}{c}0.0669 \\
(0.0561)\end{array}$ \\
\hline inflation & $\begin{array}{c}0.0398 \\
(0.0301)\end{array}$ & $\begin{array}{c}0.0215 \\
(0.0369)\end{array}$ & $\begin{array}{c}-0.00898 \\
(0.0423)\end{array}$ & $\begin{array}{c}-0.0258 \\
(0.0390)\end{array}$ & $\begin{array}{c}0.0137 \\
(0.0450)\end{array}$ & $\begin{array}{c}-0.0236 \\
(0.0444)\end{array}$ \\
\hline gdp_pc & $\begin{array}{c}0.0147^{* * *} \\
(0.00529)\end{array}$ & $\begin{array}{c}0.0269^{* * *} \\
(0.00778)\end{array}$ & $\begin{array}{c}0.0212^{* * *} \\
(0.00759)\end{array}$ & $\begin{array}{c}0.0186^{* *} \\
(0.00769)\end{array}$ & $\begin{array}{c}0.0221^{* *} \\
(0.00914)\end{array}$ & $\begin{array}{c}0.0214^{* *} \\
(0.00992)\end{array}$ \\
\hline m2_reserves & & $\begin{array}{c}0.00584 \\
(0.00591)\end{array}$ & $\begin{array}{c}0.00769 \\
(0.00482)\end{array}$ & & $\begin{array}{c}0.00111 \\
(0.00416)\end{array}$ & $\begin{array}{c}0.00159 \\
(0.00395)\end{array}$ \\
\hline credit_gdp & & $\begin{array}{l}0.00575^{*} \\
(0.00311)\end{array}$ & & & $\begin{array}{c}0.00739 \\
(0.00537)\end{array}$ & \\
\hline L2.credit_growth & & $\begin{array}{c}0.0123 \\
(0.00899)\end{array}$ & & & $\begin{array}{c}-8.97 \mathrm{e}-05 \\
(0.00891)\end{array}$ & \\
\hline hhcredit_gdp & & & $\begin{array}{c}0.0144^{* *} \\
(0.00654)\end{array}$ & & & $\begin{array}{c}0.0133 \\
(0.00863)\end{array}$ \\
\hline L2.hhcredit_growth & & & $\begin{array}{c}0.0294^{* *} \\
(0.0122)\end{array}$ & & & $\begin{array}{c}0.0138 \\
(0.0123)\end{array}$ \\
\hline L.gini_market & $\begin{array}{c}0.0560^{* * *} \\
(0.0212)\end{array}$ & $\begin{array}{c}0.0857^{* *} \\
(0.0343)\end{array}$ & $\begin{array}{l}0.0630^{*} \\
(0.0359)\end{array}$ & & & \\
\hline L.topincomep99 & & & & $\begin{array}{c}6.244 \\
(4.122)\end{array}$ & $\begin{array}{l}9.160^{*} \\
(5.161)\end{array}$ & $\begin{array}{c}4.913 \\
(3.778)\end{array}$ \\
\hline Observations & 588 & 417 & 388 & 408 & 324 & 298 \\
\hline No. crises & 24 & 20 & 19 & 15 & 14 & 14 \\
\hline$\%$ Total Correct & 96.26 & 96.16 & 95.62 & 96.57 & 96.30 & 95.97 \\
\hline \% Crises Correct & 8.333 & 20 & 15.79 & 6.667 & 14.29 & 14.29 \\
\hline$\%$ No-Crises Correct & 100 & 100 & 99.73 & 100 & 100 & 100 \\
\hline Pseudo R-sq & 0.181 & 0.275 & 0.274 & 0.197 & 0.224 & 0.244 \\
\hline Chi-sq & 36.29 & 44.12 & 41.52 & 25.36 & 25.90 & 27.60 \\
\hline $\mathrm{p}$-value & $6.39 \mathrm{e}-06$ & $3.14 \mathrm{e}-06$ & $9.13 \mathrm{e}-06$ & 0.000656 & 0.00388 & 0.00209 \\
\hline AIC & 180.3 & 138.4 & 132.2 & 119.2 & 111.5 & 107.4 \\
\hline
\end{tabular}

Robust standard errors in parentheses.

*** $\mathrm{p}<0.01,{ }^{* *} \mathrm{p}<0.05,{ }^{*} \mathrm{p}<0.1$ 
Table A14: Extended estimation including credit, labor and business regulation indices

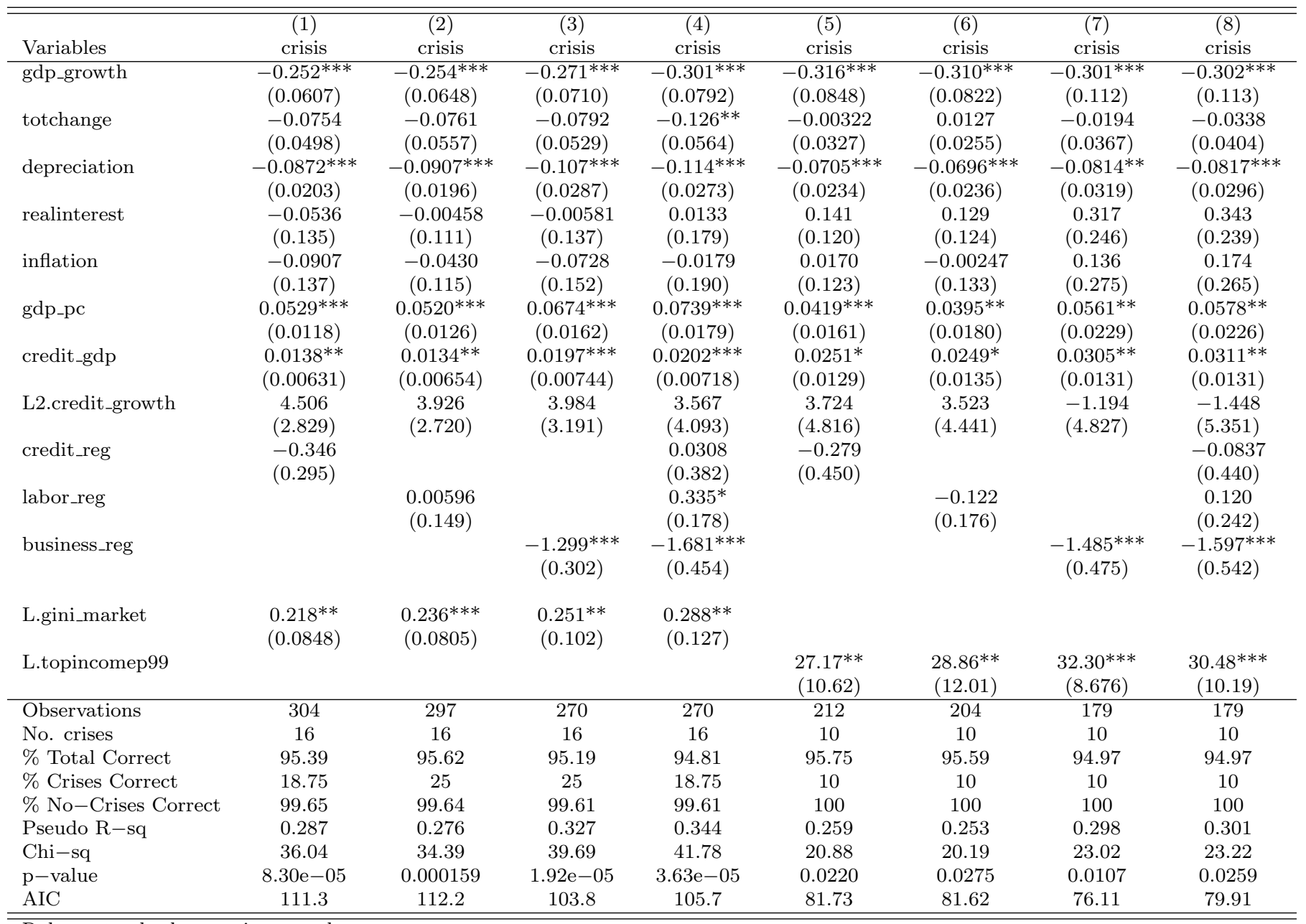

\footnotetext{
Robust standard errors in parentheses.

${ }^{* * *} \mathrm{p}<0.01,{ }^{* *} \mathrm{p}<0.05,{ }^{*} \mathrm{p}<0.1$
} 
Table A15: Estimation with the top 1\% income share including the share price index (level)

\begin{tabular}{|c|c|c|c|c|c|c|}
\hline Variables & $\begin{array}{c}(1) \\
\text { crisis }\end{array}$ & $\begin{array}{c}(2) \\
\text { crisis }\end{array}$ & $\begin{array}{c}(3) \\
\text { crisis }\end{array}$ & $\begin{array}{c}(4) \\
\text { crisis }\end{array}$ & $\begin{array}{c}(5) \\
\text { crisis }\end{array}$ & $\begin{array}{c}(6) \\
\text { crisis }\end{array}$ \\
\hline L.gdp_growth & $\begin{array}{c}0.0102 \\
(0.0878)\end{array}$ & $\begin{array}{c}0.0457 \\
(0.0915)\end{array}$ & $\begin{array}{c}0.0159 \\
(0.0910)\end{array}$ & $\begin{array}{c}-0.0581 \\
(0.138)\end{array}$ & $\begin{array}{c}-0.00603 \\
(0.142)\end{array}$ & $\begin{array}{c}0.0387 \\
(0.130)\end{array}$ \\
\hline L.depreciation & $\begin{array}{l}-0.0265 \\
(0.0291)\end{array}$ & $\begin{array}{l}-0.0260 \\
(0.0291)\end{array}$ & $\begin{array}{l}-0.0240 \\
(0.0253)\end{array}$ & $\begin{array}{l}-0.0142 \\
(0.0316)\end{array}$ & $\begin{array}{l}-0.0114 \\
(0.0315)\end{array}$ & $\begin{array}{l}-0.0207 \\
(0.0299)\end{array}$ \\
\hline L.inflation & $\begin{array}{l}0.210^{* *} \\
(0.0913)\end{array}$ & $\begin{array}{l}0.221^{* *} \\
(0.0876)\end{array}$ & $\begin{array}{c}0.181^{*} \\
(0.0945)\end{array}$ & $\begin{array}{l}0.259^{*} \\
(0.139)\end{array}$ & $\begin{array}{c}0.268^{* *} \\
(0.121)\end{array}$ & $\begin{array}{l}0.229 * \\
(0.121)\end{array}$ \\
\hline L.gdp_pc & $\begin{array}{c}0.0412^{* * *} \\
(0.0116)\end{array}$ & $\begin{array}{c}0.0412^{* * *} \\
(0.0123)\end{array}$ & $\begin{array}{c}0.0266^{* *} \\
(0.0113)\end{array}$ & $\begin{array}{c}0.0218 \\
(0.0136)\end{array}$ & $\begin{array}{c}0.0178 \\
(0.0147)\end{array}$ & $\begin{array}{c}0.0118 \\
(0.0133)\end{array}$ \\
\hline L.share_index & $\begin{array}{l}0.00990^{*} \\
(0.00585)\end{array}$ & $\begin{array}{c}0.00950 \\
(0.00600)\end{array}$ & $\begin{array}{l}0.0176^{* *} \\
(0.00712)\end{array}$ & $\begin{array}{c}0.0204^{* * *} \\
(0.00771)\end{array}$ & $\begin{array}{c}0.0212^{* * *} \\
(0.00821)\end{array}$ & $\begin{array}{c}0.0207^{* * *} \\
(0.00713)\end{array}$ \\
\hline d_NA_Australasia & & & & $\begin{array}{l}-1.533 \\
(0.971)\end{array}$ & $\begin{array}{c}-1.691^{*} \\
(0.902)\end{array}$ & $\begin{array}{l}-1.274 \\
(0.999)\end{array}$ \\
\hline d_South_Europe & & & & $\begin{array}{c}0.718 \\
(0.588)\end{array}$ & $\begin{array}{c}0.493 \\
(0.648)\end{array}$ & $\begin{array}{c}0.685 \\
(0.547)\end{array}$ \\
\hline d_East_Europe & & & & $\begin{array}{l}- \\
(-)\end{array}$ & $(-)$ & $(-)$ \\
\hline d_Nordic & & & & $\begin{array}{c}1.213 \\
(0.746)\end{array}$ & $\begin{array}{l}1.152^{*} \\
(0.650)\end{array}$ & $\begin{array}{l}0.919^{*} \\
(0.506)\end{array}$ \\
\hline L3.topincomep99 & & & $\begin{array}{c}11.52 \\
(8.438)\end{array}$ & & & $\begin{array}{c}20.67^{*} \\
(10.66)\end{array}$ \\
\hline Observations & 340 & 339 & 335 & 340 & 339 & 335 \\
\hline No. crises & 15 & 15 & 15 & 15 & 15 & 15 \\
\hline$\%$ Total Correct & 95.88 & 95.87 & 95.52 & 95.59 & 95.87 & 95.52 \\
\hline$\%$ Crises Correct & 6.667 & 6.667 & 6.667 & 6.667 & 13.33 & 6.667 \\
\hline$\%$ No-Crises Correct & 100 & 100 & 99.69 & 99.69 & 99.69 & 99.69 \\
\hline Pseudo $\mathrm{R}-\mathrm{sq}$ & 0.186 & 0.197 & 0.182 & 0.269 & 0.292 & 0.241 \\
\hline Chi-sq & 22.92 & 24.17 & 22.35 & 33.12 & 35.84 & 29.52 \\
\hline $\mathrm{p}$-value & 0.0110 & 0.00717 & 0.0134 & 0.00711 & 0.00304 & 0.0206 \\
\hline $\begin{array}{l}\text { AIC } \\
\text { Robust standard errors in parentheses } \\
{ }^{* * *} \mathrm{p}_{\mathrm{i} 0.01,}^{* *}{ }^{\mathrm{p}} \mathrm{0} 0.05,{ }^{*} \mathrm{p}_{\mathrm{i}} 0.1\end{array}$ & 122 & 120.7 & 122.2 & 119.8 & 117 & 123 \\
\hline
\end{tabular}

\footnotetext{
Robust standard errors in parentheses.

$* * * \mathrm{p}<0.01,{ }^{* *} \mathrm{p}<0.05, * \mathrm{p}<0.1$
} 
Table A16: Estimation with the top 1\% income share including the share price index (growth rate)

\begin{tabular}{|c|c|c|c|c|c|c|}
\hline Variables & $\begin{array}{l}(1) \\
\text { crisis }\end{array}$ & $\begin{array}{l}(2) \\
\text { crisis }\end{array}$ & $\begin{array}{l}(3) \\
\text { crisis }\end{array}$ & $\begin{array}{l}(4) \\
\text { crisis }\end{array}$ & $\begin{array}{c}(5) \\
\text { crisis }\end{array}$ & $\begin{array}{l}(6) \\
\text { crisis }\end{array}$ \\
\hline L.gdp_growth & $\begin{array}{c}-0.0240 \\
(0.102)\end{array}$ & $\begin{array}{l}-0.0115 \\
(0.0972)\end{array}$ & $\begin{array}{c}-0.0267 \\
(0.0970)\end{array}$ & $\begin{array}{l}0.0105 \\
(0.123)\end{array}$ & $\begin{array}{l}0.0319 \\
(0.119)\end{array}$ & $\begin{array}{l}0.0290 \\
(0.116)\end{array}$ \\
\hline L.totchange & $\begin{array}{c}0.0697^{* * *} * \\
(0.0157)\end{array}$ & $\begin{array}{c}0.0812^{* * * *} \\
(0.0168)\end{array}$ & $\begin{array}{c}-0.000384 \\
(0.0344)\end{array}$ & $\begin{array}{c}0.0958^{* * *} * \\
(0.0169)\end{array}$ & $\begin{array}{c}0.117^{* * *} \\
(0.0178)\end{array}$ & $\begin{array}{c}0.0417 \\
(0.0430)\end{array}$ \\
\hline L.depreciation & $\begin{array}{l}-0.0287 \\
(0.0316)\end{array}$ & $\begin{array}{l}-0.0301 \\
(0.0317)\end{array}$ & $\begin{array}{l}-0.0312 \\
(0.0312)\end{array}$ & $\begin{array}{l}-0.0271 \\
(0.0329)\end{array}$ & $\begin{array}{l}-0.0244 \\
(0.0331)\end{array}$ & $\begin{array}{l}-0.0327 \\
(0.0344)\end{array}$ \\
\hline L.realinterest & $\begin{array}{c}0.328^{* * *} \\
(0.0982)\end{array}$ & $\begin{array}{c}0.339^{* * *} \\
(0.0958)\end{array}$ & $\begin{array}{c}0.248^{* * *} \\
(0.0845)\end{array}$ & $\begin{array}{c}0.428^{* * *} \\
(0.114)\end{array}$ & $\begin{array}{c}0.421^{* * *} \\
(0.0949)\end{array}$ & $\begin{array}{c}0.339^{* * *} \\
(0.0923)\end{array}$ \\
\hline L.inflation & $\begin{array}{c}0.135 \\
(0.112)\end{array}$ & $\begin{array}{c}0.152 \\
(0.104)\end{array}$ & $\begin{array}{l}0.0601 \\
(0.115)\end{array}$ & $\begin{array}{c}0.172 \\
(0.121)\end{array}$ & $\begin{array}{l}0.184^{*} \\
(0.104)\end{array}$ & $\begin{array}{c}0.131 \\
(0.111)\end{array}$ \\
\hline L.gdp_pc & $\begin{array}{c}0.0386^{* * *} \\
(0.0124)\end{array}$ & $\begin{array}{c}0.0412^{* * *} \\
(0.0136)\end{array}$ & $\begin{array}{c}0.0232^{*} \\
(0.0125)\end{array}$ & $\begin{array}{c}0.0335^{*} \\
(0.0186)\end{array}$ & $\begin{array}{c}0.0306 \\
(0.0213)\end{array}$ & $\begin{array}{c}0.0249 \\
(0.0181)\end{array}$ \\
\hline L.credit_gdp & $\begin{array}{c}0.0282^{* * *} \\
(0.00982)\end{array}$ & $\begin{array}{c}0.0285^{* * *} \\
(0.00907)\end{array}$ & $\begin{array}{c}0.0270^{* * *} \\
(0.00894)\end{array}$ & $\begin{array}{c}0.0208 \\
(0.0138)\end{array}$ & $\begin{array}{c}0.0189 \\
(0.0132)\end{array}$ & $\begin{array}{l}0.0175^{*} \\
(0.0101)\end{array}$ \\
\hline L2.credit_growth & $\begin{array}{c}2.967 \\
(3.758)\end{array}$ & $\begin{array}{c}2.635 \\
(3.509)\end{array}$ & $\begin{array}{c}2.902 \\
(3.576)\end{array}$ & $\begin{array}{c}1.085 \\
(3.807)\end{array}$ & $\begin{array}{c}1.406 \\
(3.132)\end{array}$ & $\begin{array}{c}1.336 \\
(3.433)\end{array}$ \\
\hline L.share_index_growth & $\begin{array}{l}2.138^{*} \\
(1.199)\end{array}$ & $\begin{array}{c}2.480^{* *} \\
(1.264)\end{array}$ & $\begin{array}{l}3.010^{* *} \\
(1.478)\end{array}$ & $\begin{array}{c}1.800 \\
(1.389)\end{array}$ & $\begin{array}{l}2.145^{*} \\
(1.301)\end{array}$ & $\begin{array}{c}2.351 \\
(1.441)\end{array}$ \\
\hline d_NA_Australasia & & & & $\begin{array}{c}-1.926^{* *} \\
(0.925)\end{array}$ & $\begin{array}{c}-2.173^{* *} \\
(0.873)\end{array}$ & $\begin{array}{c}-1.758^{*} \\
(0.902)\end{array}$ \\
\hline d_South_Europe & & & & $\begin{array}{c}0.937 \\
(0.917)\end{array}$ & $\begin{array}{c}0.679 \\
(0.971)\end{array}$ & $\begin{array}{c}0.842 \\
(0.711)\end{array}$ \\
\hline d_East_Europe & & & & $\begin{array}{l}- \\
(-)\end{array}$ & $\begin{array}{l}- \\
(-)\end{array}$ & $\begin{array}{l}- \\
(-)\end{array}$ \\
\hline d_Nordic & & & & $\begin{array}{c}0.174 \\
(0.971)\end{array}$ & $\begin{array}{c}0.128 \\
(0.991)\end{array}$ & $\begin{array}{r}-0.178 \\
(0.769)\end{array}$ \\
\hline d_Asia & & & & $\begin{array}{c}-1.428^{* *} \\
(0.596)\end{array}$ & $\begin{array}{c}-2.047^{*} \\
(1.068)\end{array}$ & $\begin{array}{c}-1.142^{* * *} \\
(0.408)\end{array}$ \\
\hline d_Western_Europe & & & & $\begin{array}{l}- \\
(-)\end{array}$ & $\begin{array}{l}- \\
(-)\end{array}$ & $\begin{array}{l}- \\
(-)\end{array}$ \\
\hline L.topincomep99 & $\begin{array}{c}24.34^{* * *} \\
(6.465)\end{array}$ & & & $\begin{array}{c}34.16^{* * *} \\
(9.450)\end{array}$ & & \\
\hline L2.topincomep99 & & $\begin{array}{c}27.18^{* * *} \\
(7.574)\end{array}$ & & & $\begin{array}{c}37.68^{* * *} \\
(10.06)\end{array}$ & \\
\hline L3.topincomep99 & & & $\begin{array}{c}20.89^{* * *} * \\
(8.035) \\
\end{array}$ & & & $\begin{array}{c}27.62^{* * * *} \\
(9.833) \\
\end{array}$ \\
\hline Observations & 337 & 336 & 332 & 337 & 336 & 332 \\
\hline No. crises & 15 & 15 & 15 & 15 & 15 & 15 \\
\hline$\%$ Total Correct & 95.85 & 96.13 & 95.78 & 95.85 & 96.43 & 96.08 \\
\hline \% Crises Correct & 6.667 & 13.33 & 6.667 & 6.667 & 20 & 13.33 \\
\hline$\%$ No-Crises Correct & 100 & 100 & 100 & 100 & 100 & 100 \\
\hline Pseudo R-sq & 0.173 & 0.189 & 0.149 & 0.222 & 0.246 & 0.192 \\
\hline Chi-sq & 21.20 & 23.21 & 18.24 & 27.25 & 30.19 & 23.48 \\
\hline $\mathrm{p}$-value & 0.0197 & 0.00999 & 0.0510 & 0.0388 & 0.0170 & 0.102 \\
\hline $\mathrm{AIC}$ & 123.5 & 121.4 & 126 & 125.4 & 122.4 & 128.7 \\
\hline
\end{tabular}

Robust standard errors in parentheses.

*** $\mathrm{p}<0.01,{ }^{* *} \mathrm{p}<0.05,{ }^{*} \mathrm{p}<0.1$ 